\title{
Byzantine church chant and Islamic art music on the English recorder: theory and practice
}

\section{DEMETRIOS E. LEKKAS ${ }^{\star}$}

^Mathematician, composer; author \& tutor (ret.), Studies in Greek Culture, Hellenic Open University, Patras Greece. - ja-dim@ @otmail.com

The purpose of this paper is to demonstrate the natural appropriateness of the English-drilled and fingered recorder for playing and teaching the basic archetypal movable intervallic structures of Byzantine chant and Islamic art music. The approach lies in the following steps: i. reference to key epistemological features of the research conducted in this quest, ii. historical and functional identification of the said basic structures, by tracing their common central primary diatonic modal cell: the "spondeiac hexachord"; this is achieved by combining historical and systemic considerations; iii. direct attribution of their genesis to the drilling of primary flutes; iv. integral structural synthesis and exposition of both systems and their primary evolution as generated by the spondeiac hexachord; v. identification of the precise drilling and fingering scheme involved, with special focus on the Islamic nāy and the English recorder; vi. arguments underlining the superiority of the modern standard English recorder as a medium for these musics, supporting its adoption and propagation and recommending the manufacture of new "sopranone" and "tenorone" instruments in B b $(\pi)$; vii. a full corresponding fingering chart for the English recorder, thoroughly explained and annotated.

\section{Introduction 1. On epistemic causality}

In researching intervallic and modal histories of the past, the standard question posed by history and other related humanities is "how we know": from which sources we draw our facts, whether archaeological finds or written depositions of witnesses.

However, all this material and anecdotal reservoir and the obsessive preoccupation with it is not at all the concern of epistemic and scientific research towards confirming and accepting a theory, least of all of mathematics. Science is not a chronicle of events or an inventory of artefacts or a collection of essays. First of all, these "sources" are nothing complete: they are incidental collections of what has been found so far, out of all that may have been made and written and lost, among an indeterminate inestimable variety of things that have never been made or written. And, what's far worse, this concoction coming down to us is already largely subjective.

In fact, there is a negative virtue to tradition and heritage; and it stems from the fundamental logical asymmetry between affirmative and negative clauses and ideas, much as the current "tone" tends to neglect and downplay or totally ignore this fact: a negative relic or account can deem some theoretical frame incompatible and pretty much push it towards definitive rejection; however a positive relic or a confirming or asserting account can only deem the said frame compatible, and is incapable of sanctioning it towards a secure acceptance. In still other words, negative data and factually contradicting information is an absolute secure "no", whereas positive data and factually affirmative information is no more than a relative unsure "perhaps": a verified no is a definitive no, whereas a verified yes is a tentative yes; whoever does not understand that should try again or should revert back to basic logical training.

In pure epistemically established thought, we are concerned with systemic features, not with relics made and found or, especially, with accounts given or with opinions conveyed. All is judged on the basis of unfounded creative tentative null hypotheses: conjectural what-ifs, based on intuition and inspiration only, brainstormed, in no way requiring "factual" or "reported" confirmation, assumed and then kept or dropped based solely on one criterion: on their superior systemic congruence to pure and established epistemological criteria like Occam's razor. No man-made material remains or witnesses' accounts are required or needed or acceptable as relevant or even possible, say, for universal attraction, or for atoms and molecules, or for the creation of the solar system, or for drifting tectonic plates, or for the cause of malaria, or for the evolution of multi-cell organisms or for the ancestry of dolphins. 
Similarly, no such thing is required or even truly pertinent for the tracing of the past and generation of musical scales, like pentatonic, Byzantine, Islamic or Pythagorean ones. A small good set of inspirational systemic null hypotheses will suffice for the sciences. The quest for real, reliable sought-after causal materials and mechanisms shaping modal Ur-cells will be more than plenty. It is a conviction of the sciences that whatever is epistemologically rigorous and well-founded will be readily recognized by its longevity, systemic stability and historical resilience throughout ages, places, times, even among traditions that are unrelated to one another. Precious heritages, on the other hand, lacking systemic strongholds, mutate fast or even fall apart rapidly, to the point of getting deformed practically beyond recognition in a few generations, despite sacred values accredited to them and their preservation by extreme conservatisms.

Thus, when someone comes and shows us pentatonic or heptatonic classical Chinese or Indian or Mesopotamian or Egyptian or Greek or Byzantine or Islamic or Occidental tono-modal systems, if we are not historically-minded actual chroniclers, but we are epistemologically astute scientists, all especially if we are mathematicians, we do not ask what it is and how we know and who said what, because epistemological thought is coldly indifferent to memoirs. We ask one key question: Why? Why were the pentatonic or classical Chinese or Indian or Mesopotamian or Egyptian or Greek or Byzantine or Islamic or Occidental tono-modal systems what they are alleged or known to have been? And, if we are not given a satisfactory answer regarding cause, we accept nothing, because it is within the nature of our work to function in systemic rigour, and that is the only "proof"; and, if we are given nothing, we try to come up with a good null hypothesis of our own on our own, out of the top of our heads.

The supreme and only crux of scientific quest is confirmed causality (Gr. aitıótns: aetiotēs), involving

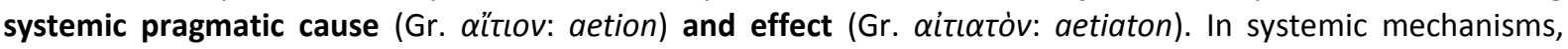
theory is an abstract causality map, whereas source and onset are concrete causal mechanisms; down the road, observed phenomena, objects and processes are systemic effects. Yet, these same observed phenomena, objects and processes, if viewed in the opposite sense, seem like causes and sources indeed; yet they are causes and sources of information and cognition, whereas scientific source and theoretical ambit (as in coining "a" scientific theory) is a goal here. The directional senses of these two flows are opposite. Classical orthodox

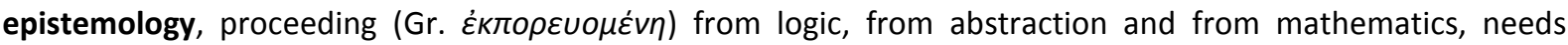
patent secure systemic depots: not impressions, not renditions, not terminals, especially not motivations or goals or utilities.

There exists of course a tricky situation, tough for the layman, of two-faced arrows, logical / argumentative equivalences regarding causality, "the converse is also true" "if and only if"; a treacherous confusion lurks between causes and effects within a gloomy fog surrounding whether or just simply when we are talking about source and terminus of a systemic causal mechanism or about source and terminus of how we know. Does the inverse arrow mean that the effect is also the cause of the cause? No way... Direct, inverse and two-way arrows of consequence and inference are abstract models that mean nothing ex ante; it depends on how we use and apply them and it is up to us every time to interpret, employ and keep or reject and describe them.

In the mother disciplines of well-founded and organized thought the sciences, i.e., in logic and in mathematics, it is unthinkable to ask why polar bears are white and get a reply "in order to..." etc. No scientific question regarding semantic flow of systemic causality shall be answered with a purpose or a plan. The archetypal Greek model syntax of the Greek language knows three types of cause: necessitating cause

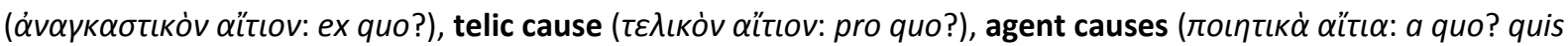

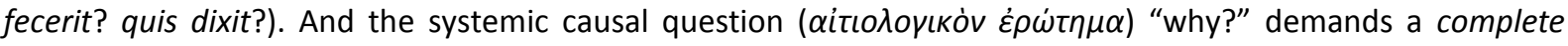
systemic necessitating cause; no systemic haphazard "telic causes" (= to achieve what?), no systemic circumstantial ill-conceived necessitating causes - much as those may be corresponding to a confusing observational or cognitive or motivational set of pseudo-causes (how do I know? where have I observed it?)especially not some agent cause (who did it? who said it?). Sources, accounts, narratives of "confirmation" are but incomplete subjectivities and plain versions of poetic nature at the bottom line.

All in all, what we do need here is a good unsubstantiated null hypothesis yielding a rigorous account of a totally minimal number of original "protoplast" Ur-cells, how they may have appeared and surfaced, how they did get subdivided into steps, how they then got hinged to one another into forming Ur-scales, what Ur- 
scales, how those mingled to reproduce and procreate descendants, what descendants, what posterior adjustments and "corrections" these Ur-scales and their early descendants underwent by generations, what they crossed and evolved into, why and why and why... It ought to be obvious to the reader that this is a systemic theory similar to a valid physiological / biological quest, and cannot possibly be rejected or even criticized by areas of knowledge doing their job in different ways: this is the top-notch most reliable and acceptable way which mankind has created regarding the study of reality.

\section{Introduction 2. On the measuring units used in this text}

Three alternative equally tempered subdivisions of the diapason / octave are used throughout this paper in order to quantify and measure intervals.

a. $\mathbf{M K}(\div 3)$; these are an offshoot of the familiar logarithmic $53^{\text {rds }}$ of the octave, widely known to us as Holder's commas. ${ }^{1}$ An equal temperament of the diapason / octave by 53 (called "53et" or also "53-tet" or "53edo") has traditionally been widely known since Chinese antiquity at least, as an optimum cyclic subdivision according to Joseph Yasser, in a series of successive improvements of Pythagorean goodness of fit for the dioxeia / perfect fifth (or alternatively and equivalently for the syllaba / perfect fourth and/or the epogdoos tone), and then noted favourably by Mercator (which is why its symbol used here by the author is MK in his honour) and adopted in Europe by many noted theorists and instrumentalists in the $19^{\text {th }}$ C. -notably R.H.M. Bosanquet-, being part of the familiar established sequence:

$$
\mathbf{5}, 10, \mathbf{1 2}, 24,36, \mathbf{4 1}, \mathbf{5 3}, 106,159,212,265, \mathbf{3 0 6}, 612,665 \ldots^{2}
$$

The chief reason why the author chooses to use this particular configuration basis in principle is that it is a particularly widespread, age-old, familiar, recognizable and handy numerical benchmark universally. It has been broadly adopted and used as a key reference frame throughout several ages and cultures. The mathematical fact is that the 53et "Holdrian" equal temperament figures a precipitously superior excellent improvement over preceding ones for approximating prime factor 3 and its principal intra-octave manifestation in the perfect fifth of 3/2 (31.003 MK), while also incidentally affording a splendidly close approximation to prime factor 5 and its principal intra-octave manifestation in the just Natural / Zarlinean major third of 5/4 (17.062 MK).

The next question raised is how this equal temperament happens to perform, incidentally of course, as a candidate for the spondeiac soft diatonic system used in the high refined sophisticated art terrains of Byzantine and classical Islamic music. As the author has painstakingly shown and argued here in the present paper and elsewhere, the evolutionary genealogy of the spondeiac soft diatonic system is epistemologically assumed to have begun with the original instrumental aliquot / isometric homalon (Gr. $\dot{\boldsymbol{o}} \boldsymbol{\mu} \alpha \boldsymbol{\lambda} \dot{\boldsymbol{v}} \mathbf{v}$ ) / auletic / piping subdivisions, whose (modulo 2) steps also have prime factors 3, 5 and 11 (skipping 7); therefore, it runs in just three (3) dimensions (ignoring factor 2 that is, which does not count as a dimension because it is modular and indifferent). In the next evolutionary modification, the spondeiac "correction" also does away with prime factor 5, leaving behind a much more flexible and versatile pair of prime factors: just 3 and 11. In other words, the spondeiac horizon constitutes an actual 2-dimensional subsystem of the undecimal / Ptolemaic / Zalzalian system, which is 4-dimensional in its full deployment as it has prime factors $3,5,7,11$.

All that is left to do, then, is to check the crucially indicative performance of the 53et Holdrian equal temperament only with respect to prime factor 11 and its principal intra-octave manifestation in the undecimal / Ptolemaic / Zalzalian superfluous fourth of $11 / 8$, coming out as nearly $24.350 \mathrm{MK}$. This value lies rationally extremely close to $241 / 3$. So now we are faced with two choices: prima facie, we could move

\footnotetext{
${ }^{1}$ See Holder, Ref. [12]. Also see Yasser, Ref. [35].

${ }^{2}$ See, indicatively, for all except the first and last ones cited, Jeans, 1968, ch. V, last sect., p. 188. Also check widely accessible Monzo, 2021, entry: "612". In general, by absolute errors, there are no multiples of 12et conceivable after 36et, no multiples of 41 et acceptable at all, and then no multiples of 53et applicable after 265et and no multiples of 306et except 612et.
} 
on straight to an equal temperament by $53 \times 3=159,{ }^{3}$ significantly increasing the temperament number and slightly tarnishing the primary Holdrian goodness of fit vs. the perfect fifth and the secondary one vs. the major third, granted that the systemic procedure clearly allows us to do so -given that we have legitimate license to employ integer multiples of 53 as long as we stay below the next approximating improvement of the dioxeia / fifth at 306; and we are indeed fine, as 159 is within this limit. Yet, for the deep universal cultural reasons of convenient conception, cultural habituation, spontaneous recognition and easy comparison, the author and all his circle have decided or agreed to proceed with a generalized acceptance of the more imaginative and extremely eloquent solution of a "trichocommatic" twist to the 53 t, treating its multiple 159 as " $53 \times 3$ ". Thus, we end up expressing sizes of intervals in equal-tempered commas for Pythagorean and just ratios like before, but handily broken in thirds for intervals from the undecimal / Ptolemaic / Zalzalian layer. This "variant" then can be described as "(53×3)et"; its units, annotated as "MK $\div 3$ " or even just simply as $\mathbf{M K}$, beyond a certain point, are understood as occasionally accompanied by legitimate fractions $1 / 3$ and $2 / 3$ and none other as needed, without anybody ever raising questions, merely because the idea is crystal-clear and lucid.

One more remark is due here, but without elaboration, as it constitutes a rather involved issue meriting special attention elsewhere. Equal temperaments assess their goodness of approximation to intervals by laying down an "error" for each. These errors are expressed either i. in some external generalized logarithmic unit, in which case the error is called absolute, or ii. in the particular temperamental units, in which case it is called relative. Thus, without going in depth, an effect is generated, which we could call equal-temperament approximating paradox. Suppose for example that we approximate an interval, say the just minor third, by 12et equal-tempered half-tones. If we double the number into a 24et of equaltempered quarter-tones, the absolute error will not change; however, as the subdivision becomes finer and finer, the width of the temperament unit, basis of comparison for relative error, becomes smaller; then the same absolute error, compared on the basis of a smaller relative unit, grows, being doubled in this example. Thus, e.g., the error of a perfect fifth for 5et and its double 10et is the same, and only improves at 12et; however, an intermediate 7et does yield a smaller relative error than 10et. Extreme caution has to be exercised, then, as we go from 12 to 24 to 36 etc., or from 53 to 106 to 159 etc. regarding what happens to relative errors, true deep standard basis for our assessment of goodness of fit. ${ }^{4}$

b. sx; the author has called these intervallic width units "equal-tempered schismas" for reasons related to their size that are not of true relevance here -and, on closer scrutiny, he is not alone in this observation, much as others prefer symbol sk. Unlike what appearances suggest, the author did not originally form the idea for testing them by taking one extra full step further along Jeans's list, checking the next optimal approximation of 306. Had he done that, he would have seen that the 306et figures a modest next absolute improvement over the preceding ones for approximating prime factor 3 and its principal intraoctave manifestation in the perfect fifth of 3/2 (178.999 sx), but its approximation to prime factor 5 and its principal intra-octave manifestation in the just Natural / Zarlinean major third of 5/4 gets as poor as can be: 98.510 . However, since this particular value is very close to $981 / 2$, the idea might arise, just as before, of keeping the unit and splitting it in halves, rather than jumping into doubling the temperament number straight towards a 612et. Unlike before, with 53, though, there seems to be no reason to consider taking half-units here because there is no traditional or cultural or experiential advantage attached to 306et; it is just another number that means pretty much nothing to anybody, whereas 612 is already known as such. Thereupon, of course, having dealt with that and decided that 612 is fine, one would have to check prime factors 7 and 11 sequentially towards imponderable results in what looks like a guaranteed losing battle. However, as it unpredictably emerges at the end of this road, that is not the case at all: it turns out that the 612et, an excellent relative number for prime factor 3 (3/2: $357.997 \mathrm{sx}$ ), exhibits a fully incidental fitting performance ranging from excellent to sufficiently good as regards all three subsequent prime factors of concern to us: 5 (5/4: $197.020 \mathrm{sx}$ ) and 7 (7/4: $494.101 \mathrm{sx}$ ) and 11 (11/8: $281.172 \mathrm{sx}$ ). This concurrence makes it an ideal measuring tool for us regarding general systemic theoretical use.

\footnotetext{
${ }^{3}$ Ref. [18]. For obvious literal connotations, the author calls its unit a trichocomma, represented ideally by $\Delta \dot{w}^{\circ}+$, ratio $243 / 242(\approx 1 / 3$ MK). Others have named it a "rastma", evidently in association to maqām rast. 159 is perfectly valid for a dioxeiac equal temperament, as $53 \times 3$ is less than next optimizer 306 .

${ }^{4}$ Cf. footn. 25 .
} 
This is not now the author came to this startling conclusion many years ago while in college ca. 1972; in the process, he found out that 612 had occasionally been mentioned before for reasons probably close to the ones laid out in this section. ${ }^{5}$ The pathway of the author was quite different, at a time (early 1970's) of college computation centres with programmes on decks of perforated cards. His original test consisted in analytically picking a large sample of intervals, weighting it and coming up with a complicated algorithmic comparative statistically accounted test of goodness of fit, selecting a mix, devising alternative quantitative criteria and performing, heuristically yet sequentially, one by one on all equal temperaments from 12 to 2000, where the 612et came out as the overall champion without a shade of doubt holistically. The entire account has been reported by the author in a conference of the Ionian University and published in the proceedings. $^{6}$

c. Cents (common abbreviation: cts); these units are none other than the all-familiar 1200et or "centimal system", derived from the 12 equal-tempered half-tones (TS) of Pythagorean origins, each further logarithmically subdivided into 100 slices each. Cents are also used here because they constitute an absolute measure of subjective magnitudes, known to everyone in music and used comparatively and capitally -all especially in any function related to tuning and intonation systems.

\section{Primitive music; the flute}

Presumably, picking up hollow bones and blowing into them has been one of the chief methods of making music since the early days of mankind. It has been argued that a ritual imitation of speech and sounds from nature has played a key role here. The male sexual symbolic connotation of pipes has also been stressed. ${ }^{7}$ However these considerations no longer suffice for explaining the striking evidence of pitch- and intervalconsciousness several millennia into the past, as revealed by numerous prehistoric flutes that keep being unearthed. Thus, we see fit to turn our attention to another equally acknowledged facet of primitive shamanism: worship of the supernatural.

An additional null hypothesis can be drawn from the abundant evidence showing that prehistoric people used to incorporate sacred music in worshipping the spirits of dead ancestors and animals: music produced by blowing into bones would have been interpreted as the "voice" or "breath" of the defunct. ${ }^{8}$

In so doing, our ancestors undoubtedly familiarized themselves with the perfect sounds of octave, fifth and fourth; over and over, from time immemorial, these intervals would have been produced and registered by overblowing sacred bones, horns and all kinds of whistle pipes, bugles, signaling trumpets and horns constructed in their similitude from other materials, such as reed, wood or metal. Evidence, again, shows that, in many instances, the intervals themselves came to be venerated and were elevated to the status of basic vocabulary in a sacred musical dialect. In due time, people realized that pitch varies with the length of the pipe; it was not too long until they understood that varying the length was feasible on a single pipe, if finger-holes were drilled in it. Thus, simple end- or rim-blown flutes were born. In time, these pipes were equipped with notches; later, new techniques and devices -side-blowing, slits, mouthpieces- generated new offshoots. In this fashion, new families emerged: whistles / fipples / flageolets, side flutes, single and double reeds, trumpets.

Apart from technical features, or rather as a result thereof, the ear distinguishes among these instruments on the merit of their different timbres and volumes, while length affords a variety of ranges. From another point of view, different finger-hole configurations produce various modal structures. Each time, the drilling pattern induces a primary scale which i. is expanded in range through overblowing and ii. can be bent or altered by adjusted breathing, half-covering, cross-fingering and/or drilling of additional holes. Much later, pipes would be furnished with keys, operated directly or by means of levers, thus accommodating multiple drilling and fluid modality.

\footnotetext{
${ }^{5}$ See Ref. [11].

${ }^{6}$ See Ref. [15].

${ }^{7}$ On both of these counts see, for example, Nettl, ch. 8, last sect., pp. 124-5.

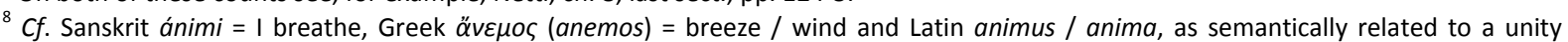

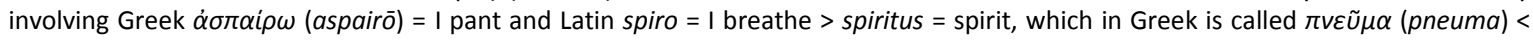
$\pi v \varepsilon \dot{\omega}($ pneō $)=$ I breathe / I blow air.
} 


\section{Drilling the one-hand flute}

Our systemic point of departure here is an original type of flute playable with one hand only. As archaeological evidence shows, one-hand pipes were quite widespread in prehistoric times, they have appeared throughout history as a prevalent type in various places at various times; indeed, they are far from obsolete even today. ${ }^{9}$ By our null hypothesis, the original idea would have been to fit a perfect fourth or fifth between the mouth of the pipe and a drilled hole, and then somehow trisect the interval on the body of the instrument; two extra drilled holes would be interposed, overall matching the three principal playing fingers: index, middle, ring. In principle, this logic yields the familiar 3-hole prehistoric / primitive type. Already the anatomy of the human hand spontaneously suggests drilling similar holes at equal distances; the idea is enhanced by the conceptual, visual and computational simplicity of the pattern. Presumably, then, drilling at equal distances is one of the oldest patterns utilized. ${ }^{10}$ In any case, it is obvious that trisecting a reference interval requires production of four pitches; therefore, in addition to the pitch coming out of the free end of the pipe, one needs to drill three holes playable with three fingers. By the same token, quadrisecting requires drilling four holes playable with four fingers, and results in the production of five pitches. Consequently, quadrisection must involve an extra finger, which could very well be the thumb. If so, the corresponding hole must be taken out of alignment with the rest and be drilled on the backside of the pipe. ${ }^{11}$

The method delineated above actively implicates the open mouth of the pipe as a tuning factor. This is not free of problems, especially in view of a culture that would be pitch- and interval-conscious enough, so as to be capable of tuning a perfect fourth or fifth correctly in the first place. If the diameter of the open mouth differs from the common diameter of finger-holes, a physical effect blows the length of the lowest segment out of proportion and can thus render the intervallic makeup unreliable. A far more dependable method would be to place the perfect interval between two similar drilled holes and then subdivide the intervening length; thus, the function of the mouth can be taken over by a last hole, to be covered by the small finger, which is the only one remaining unused. The bottom segment below this last extra hole can now be treated as an extension, and may be tuned separately at any desired interval.

If we materialize this full potential on a one-hand pipe, we end up with a set of five drilled holes playable with all five fingers and producing a hexachord -six pitches.

\section{Smooth diatonicism: the primeval homalon / auletic variety}

Amongst all four subdivisions implied in the previous section, i.e., aliquot tri- and quadrisected fourths and fifths in visual isometry, let us now focus on two: a trisected fourth and a quadrisected fifth. ${ }^{12}$ Because of the mathematics and physics involved, these two subdivisions afford the two partially coincident primeval diatonic intervallic structures shown directly below, atop a tonic / root pitched at a (movable) re. ${ }^{13}$

${ }^{9}$ Cairo museum exhibits a one-hand ancient Egyptian nāy. In the Greek double aulos, each member of the pair was played with one hand. As another example, let us mention one-hand three-hole flutes (such as the Basque txistu) still played throughout Western Europe by a musician holding a drum in the other hand; the standard combination is known as "fife and drum" or "fife and tabor".

${ }^{10}$ Kathleen Schlesinger contends that equidistant drilling into aliquot parts is motivated by a "natural instinct of man" and discusses intervallic results thus generated; see Schlesinger, pp. 40 and 4; also see Sachs, pp. 75 and 213, who calls this spacing isometric. Pipes with equally spaced holes are ubiquitous. Existence of prehistoric flutes with unequally spaced holes does not invalidate this analysis; both equal and unequal spacings seem to be parallel strands practised by mankind for tens of millennia.

${ }^{11}$ In two-hand flutes, this hole stays put and is played with one of the fingers of the left hand. One would probably not be unjustified in inferring that a pipe without thumbhole suggests a deep origin in trisections, whereas a pipe with thumbhole suggests a quadrisecting origin.

There is a mental trap we ought to stay clear of in the upcoming analysis, as it can turn into a source of endless confusion. Practising musicians usually tend to associate a musical note with the last finger used to produce it, therefore with the lowest covered hole. Physics, on the other hand, duly ascribes the same pitch to the highest air outlet, that is to the topmost open hole; that would be the next one down. So, in talking about a D-hole, for example, two different people may be implying two different things. To avoid that, it is wise to always distinguish by specifying a D-hole fingered as opposed to a D-hole sounded.

12 Dropping the cases of i. a quadrisected syllaba / fourth, which is not common, and ii. a trisected dioxeia / fifth, which produces a pentatonic result and thus falls outside the present discussion.

${ }^{13}$ The choice of a movable $r e$, here annotated $\mathrm{D}$ for reasons of economy, is no accident. As a general principle, woodwinds are transposing instruments. Practically, re on these instruments is a fingering mark for the ring finger, a fact in accordance with the widespread idea that the movable sol-fa system and its notations are related to woodwind tablatures. Middle re sounds a concert-pitch D on C-pitched instruments, such as the standard symphonic flute and oboe; the same holds for the tenor recorder as it is presently employed and 


\section{a. Tetrachord: isometric / aliquot trisected syllaba / perfect fourth}

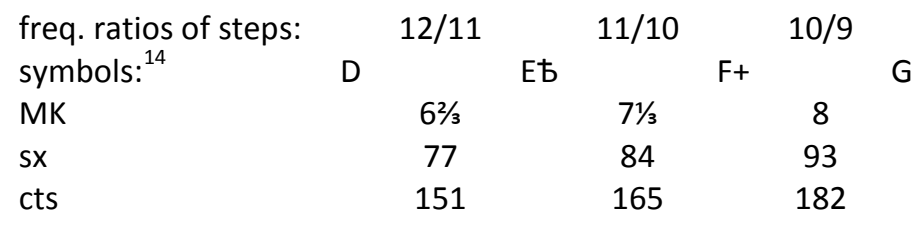

\section{b. Pentachord: isometric / aliquot quadrisected (disjunctive) dioxeia / perfect fifth}

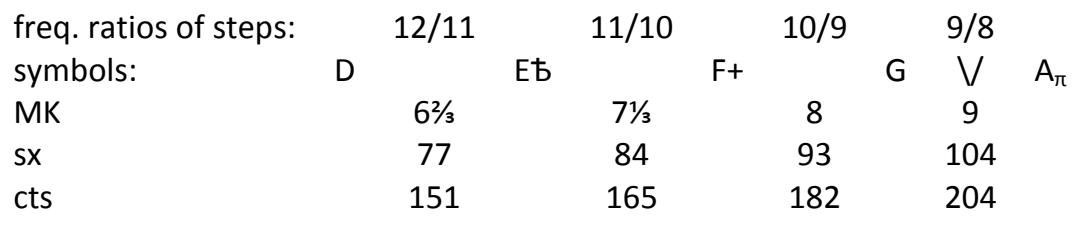

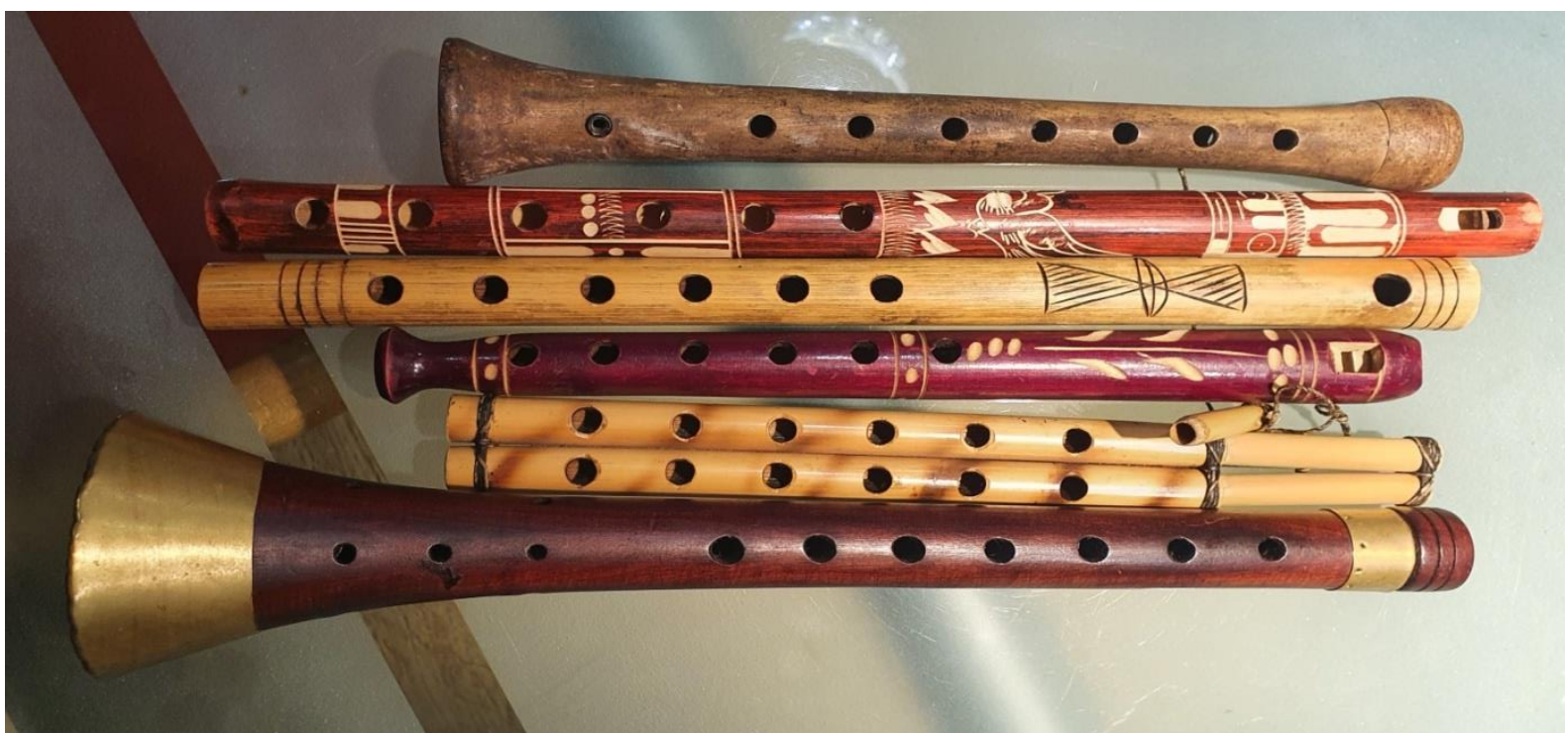

Figure 1: Identical protoplast aliquot / isometric precise auletic / homalon diatonic side drillings.

Top to bottom, pipes from: Armenia, Chile, Cameroon, Romania, Tunisia (double), Turkey.

The pentachord turns out as a combination of the preceding tetrachord with an extra disjunctive tone on top. The tetrachord is none other than the homalon diatonon (smooth diatonic), familiar from Greek music theory and mathematically accordant and fit for the model status of a protoplast Ur-cell; though first recorded numerically by Claudius Ptolemy in his Harmonics only in the $2^{\text {nd }}$ century $A D,{ }^{15}$ the homalon has evidently been around since an indefinitely old time, as our analysis suggests.

If the homalon structures were to be extended out so as to complete an octave, they would form a 7-step scale, in the same way as any other tetrachord of a perfect fourth / pentachord of a perfect fifth would; in this

thought of, much as standard notational practice for the entire recorder family is non-transposing; nevertheless, several recorder players, especially those playing other instruments as well, find it easier to play from a transposing score, and may even rewrite their parts to fit that bill.

${ }^{14}$ Note symbols used in this paper are extended Pythagorean: main nominal pitches, as well as those equipped with standard sharps and flats, $\#(\pi)$ and $b(\pi)$, are assumed to be those of the cycles of fourths and fifths. For dealing with extra in-between notes needed here, modified accidentals have been adopted. Use of such accidentals is by no means standard; in the Islam, not only does the choice of accidentals employed differ between schools, but there are also discrepancies in interpreting the same accidental. For our purposes, we have chosen to employ two accidentals of the 1932 Cairo Convention, i.e., ¥ for a "half-sharp" and $t$ for a "half-flat" (see el-Mahdi, p. 37; also, Parfitt, a). These accidentals, often associated with Meshaqa's 24-quartertone scale (cf. sect. 5, d), are used rather loosely for altering Pythagorean pitches roughly by quartertones. Two extra accidental marks, + and -, signify a note raised or lowered by a precise Didymean or syntonic comma (ratio: 81/80, width 21.5 cents), respectively. The two bars, $\backslash \backslash$ or $\bigvee$, signify attachment of an annexed whole tone (respectively proslambanomenos or disjunctive) under or over a perfect tetrachord. See also, below, sect. 5 , f.

${ }^{15}$ See Ref. [25]. 
sense, they can be considered portions of (bilobed) heptatonic scales and be institutionally incorporated in heptatonism. $^{16}$

Thus, a full homalon pentachord emerges as a primeval diatonic structure constituting a portion of a heptatonic practice-born scale. Its distinctive feature is its specific format: steps exhibiting a grosso modo gradual expanding trend going up, two bottom ones in the vicinity of $3 / 4$ and $2 / 3$ of a tone -in between semitone and tone-, followed by two steps in the region of a tone. This category of diatonicism, used in Byzantine and Islamic music and in the folk music of many peoples, is widely referred to as "smooth" or "even" or "soft" diatonicism. ${ }^{17}$ In this text, true homalon will be viewed, treated and referred to as the homalon / auletic variety of smooth diatonicism.

\section{Smooth diatonicism: the derivative spondeiac development}

Let us now pursue what happens to a pipe if we annex the extension downward as prescribed in section 2. In tuning the extension of a homalon structure, one would normally be predisposed in favour of duplicating the original generative fusing frame [fourth $Ю$ tone = fifth] by aiming for the dioxeia / perfect fifth below $\mathrm{G}$, pitched at $\mathrm{C}^{18}$ This decision induces an important secondary effect: the bottom $\mathrm{C}$ will now lie precisely one Pythagorean whole epogdoos tone below D, i.e., exactly the same interval as the disjunctive tone $\left[G, A_{\pi}\right]$ standing above the original tetrachord and completing it into a pentachord. This lower tone plays a major functional rôle in the classical Greek system; Greek theory has coined the term "tonos proslambanomenos" for it. The resulting structure is the hexatonic diatonic portion underneath.

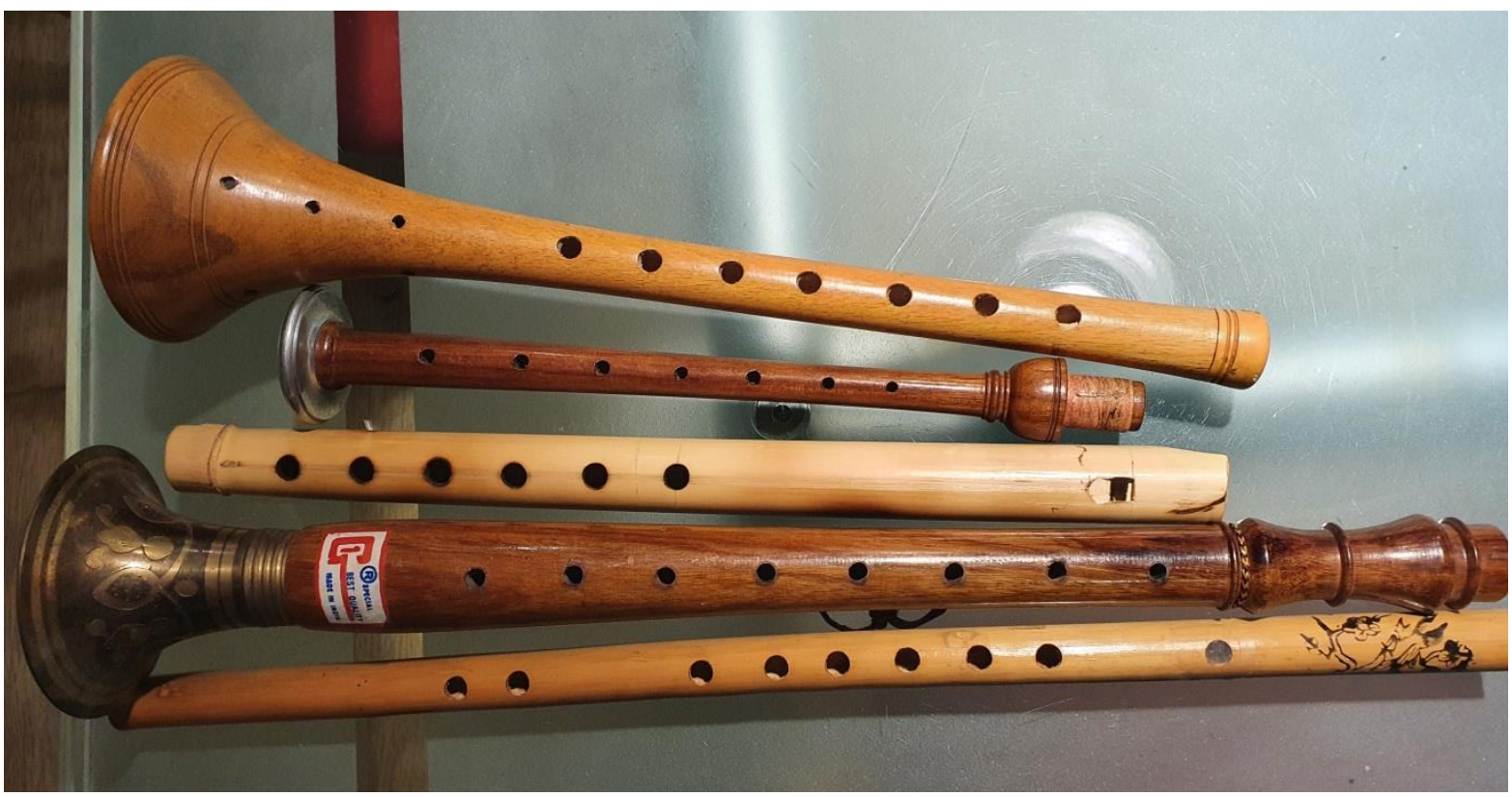

Figure 2: Equivalent precise spondeiac side drillings.

Top to bottom, pipes from: Turkey ( shifted-type), Scotland (constricted-type), Egypt (shifted-type), India (shifted-type), China (shifted-type).

\footnotetext{
${ }^{16}$ One typical way for carrying out completions of the kind is annexing an extra identical tetrachord on top; this would achieve the full heptatonic homalon scale, annotated $\left[D, E \hbar, F+, G \bigvee A_{\pi}, B \hbar, C+, D\right]$.

${ }^{17}$ Despite coincident terminology, one is not to confuse this with classical Greek soft diatonic genera.

${ }^{18}$ If the hole at the open mouth had the same size as finger-holes, the length of the end-piece would have to measure precisely $1 \frac{1}{2}$ times the standard distance between any other two adjacent holes.

One could perhaps alternatively consider tuning a syllaba / perfect fourth below $\mathrm{F}+$, thus ending up with pitch $\mathrm{C}+$, sounding sharper than $\mathrm{C}$ by a Didymean (or syntonic) comma. This practice has not actually prevailed anywhere, probably because it introduces structural and intervallic malfunctions difficult to get into within the present scope. Yet one can hardly avoid the temptation of remarking that, regardless of the rhetoric developed by music theorists from several musical cultures on the structural supremacy of the syllaba / fourth and tetrachords, and oftentimes of thirds and trichords, standard tuning of the bottom note at $\mathrm{C}$ recounts a different story: it reinforces the idea of an actual true supremacy of pentachordally calibrated tunings over tetrachordal ones.
} 
c. Homalon hexachord: homalon / auletic disjunctive dioxeiac tetra- / pentachord on D with an extension of a tonos proslambanomenos down to $\mathrm{C}$.

\begin{tabular}{|c|c|c|c|c|c|c|c|c|c|c|}
\hline ratios: & & $9 / 8$ & & $12 / 11$ & & $11 / 10$ & & $10 / 9$ & & $9 / 8$ \\
\hline symb.: & C & 11 & $D$ & & Et & & $\mathrm{F}+$ & & G & V \\
\hline MK & & 9 & & $62 / 3$ & & $71 / 3$ & & 8 & & 9 \\
\hline$x$ & & 104 & & 77 & & 84 & & 93 & & 104 \\
\hline ts & & 204 & & 151 & & 165 & & 182 & & 204 \\
\hline
\end{tabular}

A major new and potentially annoying problem arises now. In our initial tetra- / pentachordal setup, we had started out with one perfect fourth and one perfect fifth. Yet, upon extending the system through the particular procedure, we have received two perfect fifths $-[C, G]$ and $\left[D, A_{\pi}\right]-$ by design, but only one perfect fourth: $[D, G]$; the other fourth, $[C, F+]$, though not that far from perfect, is a trifle too sharp and sounds decidedly out of tune. Theoretically this is an acute fourth ( $\Sigma+/ I V+$, ratio $27 / 20)$, one comma sharper than perfect. If we wished to lower the pitch of the $\mathrm{F}+$ sounding hole just enough for transforming the fourth into a perfect one, we would be faced by the following obvious choices: i. to learn to systematically bend the note by forever adjusting our breathing and/or lip tension, ii. to move the sounding finger-hole slightly lower, iii. to constrict the size of the hole so that it may produce an F. Whatever the case, replacing the F+ by an F generates a second smooth diatonic variety and affords a new sub-branch which the author chooses to call spondeiac.

d. Spondeiac hexachord: spondeiac disjunctive dioxeiac tetra- / pentachord on D with extension / tonos proslambanomenos down to $\mathrm{C}$.

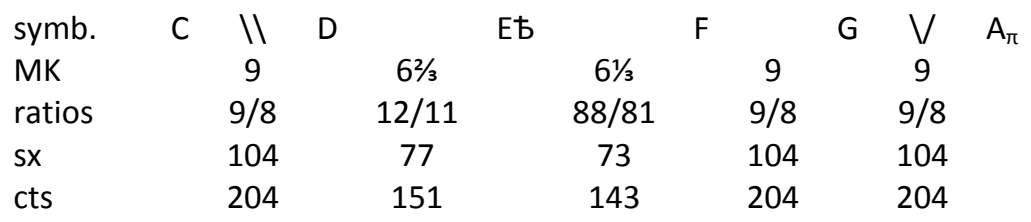

As it turns out, this systemic product constitutes the mould of a smooth diatonic variety pervading both Byzantine and Islamic diatonic solmisations, while the remaining parts of the respective tonal systems are duly shaped by transposing and refolding the above hexachord and/or by internally adjusting or "correcting" its notes.

\section{Smooth diatonicism: historical background}

The newly acquired spondeiac hexachord features one Pythagorean tone at the bottom and two identical consecutive tones at the top. In between these there comes a sequence of two nearly identical consecutive steps, both quite close to $3 / 4$ of a tone. A three-quarter-tone step had been named spondeiasmos by Greek music theorists in late antiquity. ${ }^{19}$ In recent modern literature, a step of this order of magnitude has sometimes been referred to as a spondeion, more simply. The author sees fit to adopt this term and it is in this spirit that he calls the hexachord and the implied scale spondeiac. Considering that the hexachord can very well be described as consisting of steps of $[1, \approx 3 / 4, \approx 3 / 4,1,1]$ tones, let us now solicit key references in literary sources; this will also enable us to establish our claim, made at the end of the preceding section, beyond reasonable doubt. Out of all bountiful references, let us cite the following.

a. In a passage about the modal system as it was taught and practised by his contemporary auletes, Aristoxenus $\left(4^{\text {th }}\right.$ C. BCE) writes, not without contempt or sarcasm:

\footnotetext{
${ }^{19}$ By Aristides Quintilian, pseudo-Plutarch and Baccheios Gerōn. A conjugate term eclysis for something "similar, slightly narrower and falling" was also applied when the melodic direction was descending. See respective articles in Michaelides (Ref. [18]) for both of these terms. The author regularly identifies spondeiasmos to Tiّ and eclysis to $t \mathrm{~m}$, attributing their alternation to standard effects of "attractions".
} 
... and then again some of them, looking at the drilling of pipes, separate the three deepest [tones] by [intervals of] three [enharmonic] dieses [(i.e., three quarter-tones)] from one another... ${ }^{20}$

He thus informs us of a widespread spondeiac practice in classical Athens. In fact, the entire passage makes it rather clear in that, according to the pipers' system, the bottom register of a hypophrygian aulos used to span a basic section of $[3 / 4,3 / 4,1,3 / 4,3 / 4]$ tones.

b. The great medieval Persian music theorist Mansūr Zalzal or Zulzul ${ }^{21}$ (d. 790?) was first to introduce the precise spondeiac tetrachord of $[12 / 11,88 / 81,9 / 8]$ as the diatonic foundation for Islamic music. Zalzal was master musician at the court of the Abbasid Khalifs of Baghdad in the $8^{\text {th }}$ century, and his system was recorded on frets tied on the neck of a model instrument that came to be known in the West as "the Arabic lute". The tuning, probably reflecting folk musical practice, partially reproduces the basic scale of the nāy, the ancient Middle-Eastern end-blown flute. After Zalzal died, his system fell into official disuse for about $11 \frac{1}{2}$ century, until a later great theorist of Turkic or Persian origins, Muhammad Farkhan Fārābī (878-951), discussed it in his books and adopted it as the basic scale for classical Islamic music. ${ }^{22}$

c. In a book published in 1832, Chrysanthus of Madytus, Archbishop of Dyrrachium (1770?-1846), postulated a spondeiac octochord as the model Byzantine "soft diatonic scale" within the context of his much talkedabout "reform of the Eastern ecclesiastical music". The steps of the scale were expressed in arithmetical ratios identical to Zalzal's and Fārābī's. ${ }^{23}$ Evidently, Chrysanthus knew Fārābī's treatise.

${ }^{20}$ Harmonic elements B $26 \mathrm{ff}$; see Aristoxenus: 108; based on this information, a modern scholar could include an extra diatonic "piping" chroa of $([3 / 4,3 / 4,1])$, along with the other two Aristoxenic diatonic ones, much as the ancient theorist frowns at the idea. This spondeiac chroā, substantiating smooth diatonicism in classical Athens, strongly resembles Ptolemy's homalon diatonon, six centuries its junior.

${ }^{21}$ Persian and Arabic names typically appear in European texts in a variety of spellings. The ones used in the literature are indicative at best. Though extensive use of circumflex and other additives is acknowledged as doing better justice to pronunciations, we shall not be using them in this particular text.

${ }^{22}$ Zalzal's and Fārābī's approach has passed down to us through the writings of the latter, who is better known under his Arab name Abū Nasr Muhammad al-Fārābī; see Ref. [8] for his discussion of lutes and their fretting at pp. $105 \mathrm{ff}$, modal tables at pp. $254 \mathrm{ff}$, discourse on the drilling pattern of the nāy at pp. $268 \mathrm{ff}$.

The fretting in question can be seen clearly and fully as a spondeiac hexachord (tetrachord with a proslambanomenos and a disjunctive tone) in Farmer, p. 460, figure, notes labelled: 2nd string column: “Open string (muţlaq)": (1200 - $204=) 996$ cents, "1st finger (sabbāba)": 1200 (or 0) cents, "2nd finger (Zalzal's wusţā)", 151 cents; 1st string column: “Open string (muţlaq)": (151 + 143 =) 294 cents, "1st finger (sabbāba)": (294 + $204=) 498$ cents, "3rd finger (binşir)": (498+ $204=) 702$ cents.

Actually, there is a grave systemic problem with parts of this fretting. The lute incurs inevitable chromatic discrepancies in parts of its scales because of how its open strings are tuned. To counter that, Zalzal and Fārābī apparently went ahead with certain compromises, disruptive of immutability upon transposition (see end of section): the "same" tetrachord turns out tuned differently in different registers. The great majority of the remaining frets listed in Farmer's figure are compromised thus. As we must give precedence to staying systemically consistent, we must dismiss all compromises in tunings.

${ }^{23}$ Chrysanthus, pp. $28 \mathrm{ff}$. We do not mean to become entangled in any of the several misconceptions or raging debates surrounding Byzantine chant and Chrysanthus's reform here. However, we can hardly help briefly addressing and responding to four highly controversial issues. i. It is readily understood and instantly assumed throughout Eastern Europe and the Near and Middle East that the term "Byzantine music" is used as an identifier of a genre; by this phrase we do not mean the ethnic musics of the Byzantine Empire -"music(s) of the Byzantium" is what we could call those-, but the sole official form of art music common to all areas and historical phases of the Empire, namely the liturgical chant of the Eastern Orthodox church, together with its continuations after the fall of the Empire to the present day and beyond. If it weren't so, the very term "Neo-Byzantine" would be nonsensical. After all, the Empire never called itself "Byzantine", and the adjective meant nothing to anybody in the Middle Ages. ii. On whether there are rival numerical formulations of the Byzantine diatonic scale besides Zalzal-Fārābi-Chrysantus's spondeiac, the answer is affirmative; yet all serious ones come out sounding pretty close to it; they all preserve an unmistakable spondeiac character, whereas none of them come anywhere near being as systemically accountable and internally consistent. iii. On the disputed descent of medieval Byzantine chant from classical Greek music, the author has been publishing texts (e.g., see Ref. [16] and [18],) arguing that a. during the archaic era in Greece $\left(8^{\text {th }}-7^{\text {th }}\right.$ c. BCE), Phrygian auletes introduced smooth diatonic heptatonism (of 4 spondeia and 3 tones to the octave pretty much) to a largely pentatonic indigenous culture; b. the classical Pythagorean and post-Pythagorean syntonic / "hard" diatonic developments (of essentially 5 tones and 2 semitones, simply speaking,) were a direct evolution of the Phrygian system, c. the two systems ran in parallel all through antiquity ( $c f$. Aristoxenus above, sect. 5, a), reflecting and perpetuating a sort of cultural dualism; d. musical intonation in the Eastern Empire's first few centuries gradually abandoned the syntonic / hard diatonicisms of classical Greek mathematical theory and art music, thus returning to the ubiquitous archaic smooth Phrygian system and becoming its replica, whereas the Vatican preserved the former and passed them on to Western European ecclesiastical and art music with time; e. thus the spondeiac system used in church music of the Byzantium emerges as older than and in true sense parental to the classical Greek system. iv. On whether present-day Orthodox Neo-Byzantine chant is truly Byzantine or a heavily Ottomanized offshoot, the bulk of recent research demonstrates that, upon focusing on the fundamental building blocks and material, i.e., modal cells, key melodic formulas and a basic repertoire of simple hymns, a. Neo-Byzantine ones are exactly the same as medieval Byzantine ones or at most transposed by a fifth or fourth; b. these formulas and hymns make perfect musical sense in spondeiac intonation and next to no sense in hard / syntonic; c. Ottomanization is a speculative theory that appears to be true to a smaller or larger extent, especially regarding 
d. Still within the $19^{\text {th }}$ century, Syrian / Lebanese Mikhail Meshaqa(h) or Mushaka (1800-1889) also accepted the Zalzal-Fārābī formulation as a model tuning for the basic Arab bayātī scale on note D. ${ }^{24}$ To make things easier, he equated the originally unequal "quarter-tones" into equivalent equal-tempered ones, by subdividing the diapason / octave into 24 . In his configuration, bayātī comes out as $[3,3,4 \backslash 4 / 3,3,4]$ such quarter-tones, in perfect accordance with Aristoxenus's provisional diatonic chroā of pipers. This approximate yet decidedly spondeiac intonation was spontaneously adopted and put into use by large portions of the Arab world.

e. Cypriot theorists on Byzantine music in the $20^{\text {th }}$ century developed a notable independent school of musicological thought. In their texts they have consistently been recording an approximation of the central "natural diatonic scale of the Prōtoi Ėchoi" as $[9,9,12 \backslash 12 / 9,9,12]$ dódecatēmoria. ${ }^{25}$ Given that a dōdecatēmorion is an equal-tempered $72^{\text {nd }}$ of an octave or $12^{\text {th }}$ of a tone, this formulation is equivalent both to a disjunctive systemization of Aristoxenus's piping diatonic chroā as in $a$. above $([3 / 4,3 / 4,1 \backslash 1 / 3 / 4,3 / 4$, 1]) and to Meshaqa's equal-tempered bayātī in $d$. directly preceding.

According to the analysis carried out so far, smooth diatonicism, either as primeval homalon / auletic or as reformed spondeiac, or even interchangeably and indistinguishably, is a prehistoric system of intonation spread out all over the globe through time, where and when one may encounter heptatonic scales or segments thereof. ${ }^{26}$ In Greece it became prevalent during the archaic period, juxtaposing itself to the older pentatonism which is still surviving today in the tradition of a sizeable region -as unfolded in footn. 23. Ever since then, it has been actively used throughout the ages in traditional and piping music; then, in the Middle Ages, it has been restored as the official system of Byzantine art music. Smooth diatonicism has also been practised consistently in Anatolia, the Middle East, Northern Asia and all of old Europe, in its authentic versions or in circumstantial slight tonal variants. At least part of the 9,000-year-old Jiahu flutes from China are tuned smoothly. ${ }^{27}$

A system based on a simply drilled / fingered scale may subsequently seek ways to enrich itself with extra notes, typically viewed and serving as alterations of the original established ones. This is typical of the evolution of such musics to levels of more advanced theoretical and artistic sophistication. One chief method for expanding the arsenal of available pitches is to somehow subdivide extant intervals. Another one, already mentioned in the course, is to transpose integral segments of the incumbent scale to different degrees in it, thus refolding its overlapping pieces on top of one another; both of these procedures can be applied as many times as one wishes or needs.

Formally speaking, a procedure of transposing and refolding is subject to an unconditional requirement: if it is to be carried out literally, it absolutely ought to obey the systemic principle of immutability upon

style and flavour and enriched melodic development; yet, by virtue of the fact that both of these musics share the same systemic tonal and modal infrastructures, one can hardly claim adulteration even so, let alone a generalized creolization. In addition, an opposite process of de-Ottomanization has been going on during the last 190 years following the creation of the Greek State. In any instance, commonness of the two infrastructures is strongly reinforced by the growing evidence that Byzantine music has also exerted substantial influence upon the entire Middle East and by the fact that a strict smooth diatonic consistency pervades the sum total of the timeless Anatolian traditional folk sub-stratum and about $85 \%$ of its Greek counterpart (about $10 \%$ of the rest of the latter is still pentatonic and a bare $5 \%$ is roughly syntonic). Thus, such mutual intake of influences does not disrupt the building blocks, unlike the ongoing Westernization which simply demolishes them.

${ }^{24}$ In his Risala al Šihabiya fi al Sina'a al Musiqiya (Letter to [Emir] Šihab Regarding the Art of Music); see Smith in Ref. [29].

${ }^{25}$ Stylianos Chourmouzios, Father Charalampos Oeconomos of Paphos, Theodoulos Callinicos. See, for instance, Callinicos, pp. 44 and 48 ; see also Desby, pp. 312-320. In what regards the principles pervading equal temperaments, both concerning absolute and relative errors and the "approximating paradox" exposed here in Introduction 1, sect. b, obviously, no one has realized the nasty flaw incurred and the damage done by the superficial '72et'. First fervently suggested by Aristoxenus in the $4^{\text {th }}$ century BCE (Ref. [2]), it got adopted by the 1881 CE Patriarchal Commission, and thus it has already been picked up by most Orthodox cantors and Byzantine music schools, academies and theorists. This contrivance is the sextuple of 12et, the familiar European equal temperament of 12 "halftones" (cf. pianos), conceived on and applied to the 3-limit Pythagorean system, without taking spondeiac soft diatonicism into any account at all. But its worst flaw, which is not being realized apparently, is this: despite the fact that it has the same absolute error as the piano regarding the perfect fifth, being a sextuple, it has a relative error -which is what counts in theory- that is six (6) times the error of the piano and guitar and mandolin, on account of the said paradox. As stated in footn. 2 , even regarding absolute errors, no multiples of 12 et are conceivable after 36et; 41et has broken their line way before 72 (=12×6) lines (“II"). Besides all, in 72 et: $\mathbf{T} \approx$ $12.235 \mathrm{II}, \mathrm{Tw} \approx 9.038 \mathrm{II}, \mathrm{tm} \approx 8.610 \mathrm{II}$ and $\lambda \approx 5.413 \mathrm{II}$. So?

${ }^{26}$ As before, this statement does not imply that this is the only heptatonic system one can encounter.

${ }^{27}$ See Ref. [37]. 
transposition; otherwise, it violates its own generative principle (it is NOT a transposition) and turns out self-contradictory and dysfunctional. No matter how "good" for practical purposes, it lacks what it takes for anything to be accepted as a constituent of any true consistent theory.

f. The systemic problem, which we cannot possibly pretend to begin to solve here, can be highlighted as follows, step by step. In the Pythagorean heptatonism or syntonic / hard diatonicism / subjective linear cycle of dioxeias / perfect fifths, the epogdoos tone is split into two unequal "half-tones". Out of these two, only the apotomē is a diesis / note of the same degree, because the other piece is the diesiaeon limma, and this is a step, therefore a degree-changer. However, as the cycle goes on and deploys itself, it offers only a direct catapycnōsis by Pythagorean commas, yielding nothing direct like enharmonic / "quarter-tone" dieses or like anything slightly wider (hēmiolic / in-between) or narrower (hectēmoriac / "sixth-tone"). The net result is that the Pythagorean system and incidentally the spondeiac subsystem which contains it as an integral functional subsystem of its own, including the totality of the Byzantine and classical Islamic ambit, only has one (1) chromatic diesis. Furthermore, anything that needs to be sharpened or flattened chromatically must be moved by one apotome up or down; this means that all spondeiac Byzantine and Islamic musical notes are sharpened and flattened symmetrically in an intervallic sense, yielding their symbols mutually canceling and neutering. Thus, regardless of all, Pythagorean and spondeiac alterations by one chromatic / "half-tone" always involve an apotomē / acute diesis:

- $\alpha$ or $\Delta+$ : ratio $2187 / 2048$, width 5 MK, or 58 sx, or 113.685 cents;

$\circ$ our systemic chromatic sharpening notation: Pythagorean $\#_{\pi}$, Byzantine 5 ;

o our systemic chromatic flattening notation: Pythagorean $b_{\pi}$, Byzantine ?;

Quite on the same vein, the $11^{\text {th }}$ harmonic also splits the uni-factor (prime factor 3 ) apotome into two unequal "quarter-tones", except this time they are both dieses; i.e., they are not steps, but same-degree alterations; thus, the bi-factor spondeiac tono-modal constitution (prime factors 3 \& 11) begets two different width-wise asymmetric ehharmonic / "quarter-tone" dieses, a slightly wider and a slightly narrower one:

- wider spondeiac enharmonic diesis / "quarter-tone": the acute condeficient diesis $\Delta \mathbf{w}+:$ ratio 729/704, width $2 \frac{2}{3} \mathbf{M K}$, or $31 \mathrm{sx}$, or 60.412 cents;

- narrower spondeiac enharmonic diesis / "quarter-tone": the deficient diesis $\Delta \mathbf{M}$ : ratio $33 / 32$, width $\mathbf{2} 1 \frac{1}{3}$ MK, or 27 sx, or 52.273 cents;

But this conjuncture incurs a few unexpected crucial consequences.

1. These two intervallically unequal Ptolemaic / Zalzalian enharmonic / "quarter-tone" dieses can be fused back into an apotomē, the one and only Pythagorean chromatic / "half-tone" diesis, as they are it splinters; but i. they do not cancel out mutually, and ii. two of the same kind cannot fuse into anything meaningful.

2. As a consequence, these two types of enharmonic dieses cannot be placed next to each other in a succession: they absolutely have to alternate, as in one of the former, then one of the latter, then one of the former again and so on.

3. This dictates that all spondeiac systemic notes from the Pythagorean subsystem, i.e., all 3-limit ones lying on the Pythagorean axis, i.e., $\mathbf{v} \eta, \boldsymbol{\pi} \boldsymbol{\alpha}, \boldsymbol{\gamma} \boldsymbol{\alpha}, \boldsymbol{\delta} \mathbf{\imath}$ and $\boldsymbol{\kappa} \boldsymbol{\varepsilon}$, must take (enharmonic) half-sharps and half-flats of unequal widths; in particular, they take half-sharps of the narrower size only, and half-flats of the wider size only.

4. The situation is the opposite with the two bi-factor Byzantine spondeiac notes from the purely Ptolemaic / Zalzalian realm, i.e., the 11-limit ones lying anywhere outside the Pythagorean axis, namely $\beta \mathbf{8}$ and $\zeta \omega$; they also must take (enharmonic) half-sharps and half-flats of unequal widths; except, this time, it is their half-sharps that are wider (like Pythagorean notes' half-flats), whereas their half-flats are now the narrower ones (like Pythagorean notes' half-sharps).

5. An unexpected end result of this entire fix, baffling at first, is that, whereas the Byzantine spondeiac notation needs and has four different enharmonic alteration notes (two different enharmonic half-sharps and two different enharmonic half-flats), the corresponding equivalent Pythagorean spondeiac realm 
needs and has only two, and no corresponding equivalents whatsoever for the other two. By taking a close look at the list immediately following, one sees very well why.

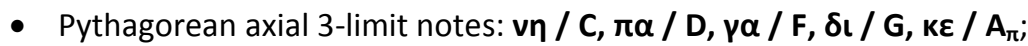

○ their enharmonic / "quarter-tone" half-sharps by narrower deficient diesis $\Delta \mathrm{M}$ : vn\} / C $\neq, \pi \boldsymbol{\alpha}$ b

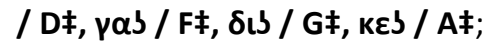

○ their enharmonic / "quarter-tone" half-flats by wider acute condeficient diesis $\Delta \mathrm{W}+:$ vnd /

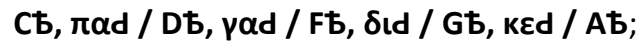

- Ptolemaic spondeiac planar 11-limit notes: $\boldsymbol{\beta} \mathbf{8}$ (/ Et), $\boldsymbol{\zeta \omega}$ (/ Bち);

○ their enharmonic / "quarter-tone" half-sharps by wider acute condeficient diesis $\Delta \mathrm{W}^{+}+\boldsymbol{\beta} \mathbf{8 H}$ $\left(/ \mathrm{E}_{\pi}\right), \zeta \omega \mathrm{H}\left(/ \mathrm{B}_{\pi}\right)$;

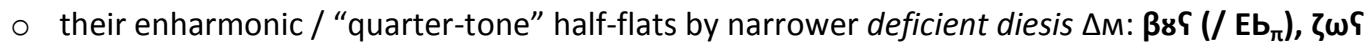
$\left(/ \mathrm{Bb}_{\pi}\right)$.

\section{Smooth diatonicism: traits}

Let us now paint a fuller picture of smooth diatonicism, by going a bit more deeply into its perceptive and functional detail. In modal terms, the most conspicuous features of all of its varieties, including both homalon / auletic and spondeiac, are:

- basic modes that are prevalently minor (with or without a quasi-diminished $2^{\text {nd }}$ degree), or "quasi-major-sounding" with neutral thirds and ambivalent sevenths;

- non-diatonic steps in secondary modes (e.g., chromatic with augmented seconds);

- casual and/or institutional bending of certain notes, even to the point of standard modes having specific prescribed or standardized or alternating bends built in; ${ }^{28}$

- an oftentimes weakened or fragmentary or fluid tonal feeling.

Although fluid, the entire smooth modal phenomenon is not at all unsystematic in Byzantine chant and Islamic music at least. Even the integrated behaviour of bending notes is usually subject to mnemonic and/or functional considerations contingent on melodic ambit, on potential presence of drones and on empirical rules of attractions and repulsions between adjacent notes. Thus, in the first place, notes of a scale or of a similar structure are divided into two gross categories as far as their degree status.

- Principal notes of fixed tonal and/or modal reference; being directly derived from the Pythagorean cycles of perfect fourths and fifths, such notes primarily occupy degrees serving as the equivalent of tonics, subdominants and dominants and, secondarily, as proslambanomenoi. Typically framing tetrachords (of a perfect fourth) and/or pentachords (of a perfect fifth), they are perceived and treated as melodically focal and tonally dependable; they are tuned strictly and immovably, their tuning becoming a bit less rigid if they are in the middle of a structure.

- Secondary notes with fluid modal and/or ambiguous tonal functions; being products of internal subdivisions, such notes primarily occupy degrees serving as levers of modal nuances and melodic colorations, and are instrumental as leading or cadential tones. Sometimes they are associated with "tetrachords" or "pentachords" framed by imperfect or shakily perfect intervals, or even with "trichords". In general, they are perceived and treated as floating and tonally unreliable, and their intonation is treated as movable, variable and bendable; beyond a certain point of drift, practice will confuse them with adjacent notes and theory may even lose track of their proper systemic tunings completely. Mostly, such notes are those carrying half-flats and half-sharps. $^{29}$

\footnotetext{
${ }^{28}$ One may wonder why old Europe was mentioned in the preceding section. Celtic music is broadly associated with equidistantly or nearequidistantly drilled chanters and is famous for bearing some of the distinct traits cited here as features of smooth diatonicism; German music annotates its sevenths idiomatically. One of the most decisive arguments comes from woodwinds (especially the recorder): a large bulk of old and current heptatonic folk flutes and pipes in Southern and Eastern Europe have equidistant drillings; so do those of other continents, including Africa and pre-Columbian Americas.

${ }^{29}$ It is typical, e.g., that Bt gets confused with a Bb if intoned too flat, or with a B if intoned too sharp.
} 
Regarding the second issue, here is a rough account of how the effects of bending, attraction and repulsion habitually work in the melodic practice of secondary degrees. The phenomena apply if the conditions cited are fulfilled and vanish if they are not.

- Unilateral upwards attraction, symb. $\uparrow$; serving a leading-tone-type function, it takes effect when the fluid note is involved in a decisive ascending melodic motion towards an adjacent principal note above; it consists in raising the pitch of the secondary note and contracting the overlying step.

- Unilateral downwards attraction, symb. $\downarrow$; serving a cadential-tone-type function, it takes effect when the fluid note is involved in a decisive descending melodic motion towards an adjacent principal note below; it consists in lowering the pitch of the secondary note and contracting the underlying step.

- Bilateral attraction, symb. $\uparrow$; it applies to secondary notes subject to both of the above dynamics interchangeably; it behaves alternatively as unilateral upwards and downwards attractions, yielding the respective effects.

- Unilateral downwards repulsion, symb. $\downarrow ; ;^{30}$ it takes effect when the fluid note is involved in serving an acknowledged modal function, if the step between it and an adjacent principal note above it is deemed "too narrow"; it consists in lowering the pitch of the secondary note and dilating the overlying step; its effect may well establish itself as permanent.

- Unilateral upwards repulsion, symb. $\uparrow$; it takes effect in similar conditions and with similar results, if the step between it and an adjacent principal note below it is deemed "too narrow"; it consists in raising the pitch of the secondary note and dilating the underlying step.

- The only other feature one may need to add here is a phenomenon of a joint bending of secondary notes; if two of them are apart by, say, a perfect fourth or fifth, and provisionally happen to assume a more principal mutual function, such as framing an important structure, there may be reason to preserve their distance; if one moves, the other one may also have to execute the same motion.

In view of all of the above, there is a strong likelihood that smooth diatonic systems have been conceived and first sounded on flutes. Even Zalzal himself must have picked up the spondeiac scale from the nāy, which he actually played. The fretting guidelines of his lute reflect the basics of piping intonation quite decisively; one may even go as far as inferring that, even today, i. the formulaic behaviour of modes corresponds to the systemic features of flute fingerings quite faithfully and ii. a "wise" manipulation of pitch bending is aptly determinable by the idiosyncrasies of how far a flute bends. Furthermore, both Fārābī and Chrysanthus were nāy players.

\section{The Middle-Eastern nāy}

In order to spot the systemically valid transposing notation on a (quasi-)equidistantly drilled flute, one needs to check its body in order to locate holes spanning fourths and/or fifths. The space between them may be found to be subdivided so as to produce visually (quasi-)trisected fourths and/or (quasi-)quadrisected fifths. This is the signature of an exact or approximate presence of the smooth diatonic setting, in its homalon / auletic or spondeiac variation. Amongst all possible woodwinds, we shall now focus on two: first on the nāy and then on what is perhaps the most precise and technically advanced instrument of the lot: the English recorder.

\footnotetext{
${ }^{30}$ Symbols coincide. Musicians and theorists in these cultures are extremely conscious of attractions; on the contrary, they never talk about repulsions; in most cases, they would probably think of a repelled tuning as the normal one and describe the systemic tuning as attracted; they would also tend to think of a cancelled attraction in one direction as a positive attraction exerted in the opposite direction.

National, regional, local and personal styles propel these dynamics in different and often sharply divergent ways, whether by applying different or no manipulations in the same instances, by interpreting the same prescribed manipulation differently, by adhering to idiomatic oral traditions, by developing special tastes etc. All these features are viewed in church chant and in the musician-orientated East not as betrayals of a composer's score but as a quintessential feature of the instrumental musician's or singer's freedom, expressiveness and charisma.
} 
Regarding the nāy, we shall concentrate on its classical Arab and Ottoman type, because this is the one standardized throughout the Middle East and Northern Africa. ${ }^{31}$ In the nāy, an

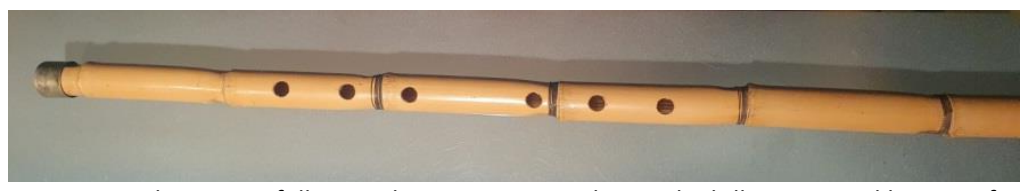

Figure 3: Islamic nāy; full equivalent precise spondeiac side drilling attained by way of two intercalated extra fingerholes. isometrically trisected fourth occurs between notes sounded by open holes № 7 and № 2 -fingerings ii and vii. ${ }^{32}$ For № 7 to sound, the lowest fingered hole is № 6, the one right above it. By our analysis, here is where our movable / transposing re / D must be set. The space below hole № 7 has a different length and sounds a pitch tuned a whole tone below re / D, thus it is an extension producing a bottom do / C.

A European musician would automatically label this a nāy "in do"; but the "nāyzen" call it a nāy "in re", obviously acknowledging the fact that do is a proslambanomenos tonos produced by an extra semiindependent extension. Theoretically the four equidistant holes trisecting the perfect fourth towards producing a smooth diatonic tetrachord would be №’s 7, 5, 4, and № 2 which sounds a (movable / transposing) sol / G.

In the nāy in question, spaces between holes №’s 7 and 5 and between №’s 4 and 2 are also visually bisected, affording two extra chromatic notes. These notes incur discrepancies that are similar in nature to the ones caused by the bulk of extra compromised notes on the lute, as analysed in footn. 22. Skipping these, the question is which variety of smooth diatonic the central tetrachord falls under. In practical terms, and without putting forth unwarranted claims of infinite precision, we notice that this instrument can also be viewed as having six aliquot segments, yet with one hole skipped. If the rest of the intervals are tuned well among themselves, and if the blowing is kept steady and the notes unbent, this setup flattens the note sounded from hole № 4 slightly, so as to contrive a realistic perfect fourth against the bottom do / C. By making the plausible and advantageous assumption that the corresponding note is an acceptably good $\mathrm{fa} / \mathrm{F}$, which it usually is, what we finally get is a spondeiac tetrachord with proslambanomenos, just like the one fretted on the Arabic lute. There is a "fortunate" side-effect to compromised chromatics. The practical final verdict is:

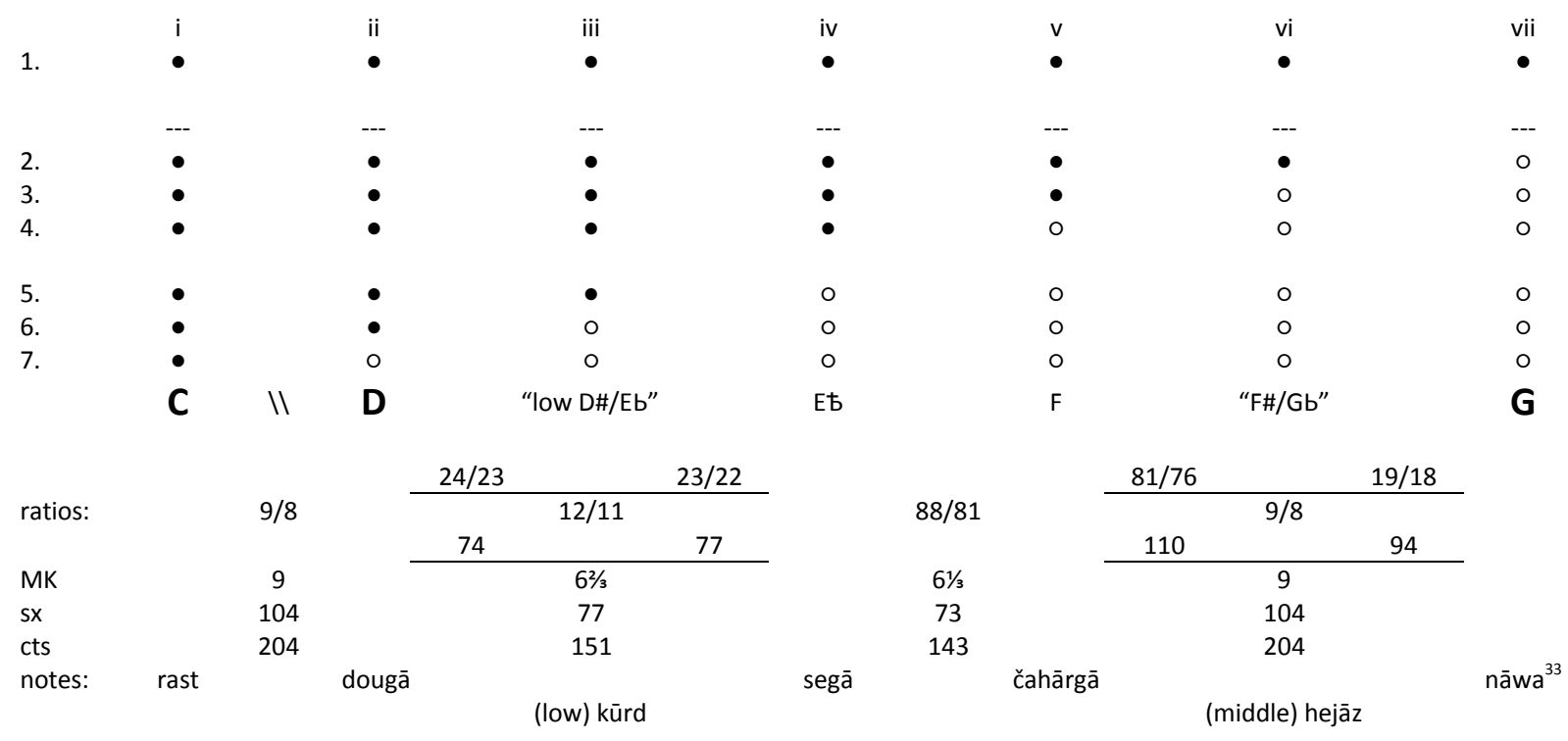

${ }^{31}$ Our analysis employs a calculated degree of mathematical idealization, in the sense that it concerns itself with the instrument maker's intentions rather than with measured precision of the actual results attained on each particular specimen. In this spirit we shall maintain our one-hand logic, although the nāy is played with two hands. That is because it basically corresponds to a one-hand instrument, played by both hands merely because it is too long. If it weren't for the one or two extra chromatic subdivisions, only five fingers would be employed, the rest staying idle as on the Japanese shakuhachi. As it is, the classical nāy uses seven fingers, and the Persian instrument, a type with one finger-hole less, only six. It is the author's impression that Persian nāys seem to come in slightly differing versions.

${ }^{32}$ Hole № 1 is a thumbhole on the back of the pipe.

${ }^{33}$ The original Persian names of the "main note series" were yekgā, dougā, segā, čahārgā, pānjgā, šešgā and hāftgā, meaning first, second, third, fourth, fifth, sixth and seventh position respectively, in a musical context. In later times, i. the last three names were dropped and replaced (pānjgā was preserved only as the name of a maqām), and ii. name yekgā was moved a fourth down from C (renamed into rast) to dominant $\mathrm{G}$ below, because of the addition of a new bass string to the oud. 


\section{The English recorder}

The English recorder is a modern organological evolution directly derived from historical baroque instruments. ${ }^{34}$ The new evolution has turned what was an approximate spondeiac drilling pattern into a precise one. This is something that we all tend to lose track of, preoccupied as we are with the recorder's translocations and transpositions and non-transpositions and with our constitutional efforts at circumventing a certain "problematic" note. This standard and widespread type of recorder has the systemic and functional makings of spondeiac diatonicism designed rigorously, placed ideally and tuned impeccably; indeed, much more impeccably than either the nāy or the Arabic lute. It can hardly be missed that this recorder is furnished with a conspicuously equidistant drilling, hosting a perfect fourth between notes sounded from holes № 7 and № 4, which means that our systemic $D$ and $G$ fall on the notes sounded from these holes (and fingered one position up, at holes № 8 and № 5). There are also two perfect fifths: one from holes № 7 and № 3 (systemic fingerings $D$ and $A$ ) and a second one from holes № 8 and № 2 (systemic fingerings $C$ and $G$ ). Furthermore, the instrument has one of its equidistant holes, № 5, accurately smaller than the rest and in the right place, thus affording a second perfect fourth sounded between holes № 8 and № 5 (systemic fingerings $\mathrm{C}$ and $\mathrm{F}$ ). Therefore, in the spirit of the systemic movable transposing terminology developed in this text, we end up with a set of seven main fingerings which make us realize that $i$. the instrument does span the systemic spondeiac hexachord (d. in sect. 4), from C (proslambanomenos) through systemic spondeiac tetrachord $D$ to $G$ up through a disjunctive tone to $A_{\pi}$ on top, and ii. it turns out that the recorder is equipped with a second extension beyond the proslambanomenos, which makes it descend an extra or "plus tone" ${ }^{35}$ spanning a full heptachord down to systemic Pythagorean $\mathrm{Bb}_{(\pi)}$.

The author reckons that we have been largely failing to grasp this striking dimension of the English recorder for the following chain of reasons: i. we usually notate recorders in concert pitch; ii. our Bb $\mathrm{B}_{(\pi)}$ systemic fingering sounds a $C$ on the descant and tenor instruments; iii. consequently, we always think in terms of nontransposed fixed pitches $\left[C, D, E_{\pi}, F \neq, G, A_{\pi}, B_{\pi}\right]$ instead; iv. as a result, we become so preoccupied with "correcting faulty-sounding fourths" $\mathrm{F}$ and "F\#/Gb" by cross-fingering, that $\mathrm{v}$. it never crosses our mind that the "wrong note" is a neutral third in another tonality, a Zalzalian one at that. So here is the set of the English recorder's principal fingerings.

\begin{tabular}{|c|c|c|c|c|c|c|c|c|c|c|c|c|c|}
\hline 1. & $\bullet$ & & $\bullet$ & & $\bullet$ & & $\bullet$ & & $\bullet$ & & $\bullet$ & & $\bullet$ \\
\hline & --- & & --- & & --- & & --- & & --- & & --- & & --- \\
\hline 2. & $\bullet$ & & $\bullet$ & & $\bullet$ & & $\bullet$ & & $\bullet$ & & $\bullet$ & & $\bullet$ \\
\hline 3. & $\bullet$ & & $\bullet$ & & $\bullet$ & & $\bullet$ & & $\bullet$ & & $\bullet$ & & ० \\
\hline 4. & $\bullet$ & & $\bullet$ & & $\bullet$ & & $\bullet$ & & $\bullet$ & & o & & O \\
\hline & --- & & --- & & --- & & --- & & --- & & --- & & --- \\
\hline 5. & $\bullet$ & & $\bullet$ & & $\bullet$ & & $\bullet$ & & 0 & & o & & o \\
\hline 6. & $\bullet$ & & $\bullet$ & & $\bullet$ & & o & & o & & o & & O \\
\hline 7. & $\bullet \bullet$ & & $\bullet \bullet$ & & ০০ & & ০০ & & ০০ & & ০০ & & ০০ \\
\hline 8. & $\bullet \bullet$ & & ০০ & & ০০ & & ০০ & & ০০ & & ০০ & & ০০ \\
\hline systemic fingerings & $\mathrm{Bb}_{\pi}$ & 11 & $\mathrm{C}$ & 11 & D & & Et & & $\mathrm{F}$ & & G & V & $A_{\pi}$ \\
\hline ratios & & $9 / 8$ & & $9 / 8$ & & $12 / 11$ & & $88 / 81$ & & $9 / 8$ & & $9 / 8$ & \\
\hline MK & & 9 & & 9 & & $62 / 3$ & & $61 / 3$ & & 9 & & 9 & \\
\hline$s x$ & & 104 & & 104 & & 77 & & 73 & & 104 & & 104 & \\
\hline cts & & 204 & & 204 & & 151 & & 143 & & 204 & & 204 & \\
\hline concert pitches, $\mathrm{F}$ instr. & $\mathrm{F}$ & 11 & $\mathbf{G}$ & 11 & $A_{\pi}$ & & Bt & & $\mathrm{C}$ & & D & V & $E_{\pi}$ \\
\hline concert pitches, $\mathrm{C}$ instr. & $\mathrm{C}$ & 11 & D & 11 & $\mathbf{E}_{\pi}$ & & $\mathrm{F} \ddagger$ & & G & & $\mathbf{A}_{\pi}$ & V & $\mathbf{B}_{\pi}$ \\
\hline
\end{tabular}

\footnotetext{
${ }^{34}$ To most people around the globe, the English drilling and fingering systems of a recorder are known and referred to as "baroque". There are certain real differences between the two systems, though not too great ones. See Ref. [1] for an Antique Sound Workshop webpage giving a concise account on the matter; the page contains informative historical and technical data and discusses that there are in fact three distinct fingering systems: (true) Baroque, English (which the page also calls Modern and Pseudo-Baroque) and German (which is the one presenting substantial differences against the other two).

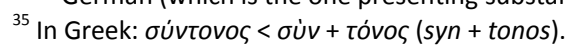




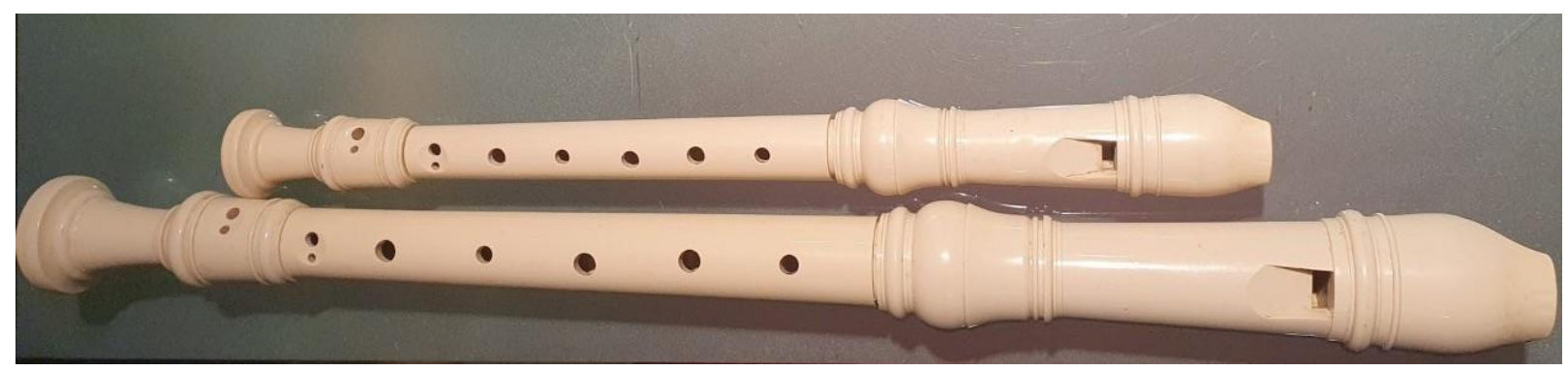

Figure 4: English-type plastic Baroque recorders, equivalent constricted-type precise spondeiac side drillings. Top to bottom: soprano or descant in $\mathrm{C}^{\prime}$, alto or treble in F.

\section{Completion of the system}

Two things remain to be done in order for us to accomplish an adequate exposition of the Byzantine (ecclesiastical) and Islamic solmisations against a corresponding display of matching English recorder fingerings. Our first task is to expand the system by transposing and refolding the focal spondeiac hexachordal mould a sufficient number of perfect fifths / fourths. The next step requires writing down the most indicative and representative scales and/or modal cells from both musical cultures. After that we shall be free to proceed to fingering charts.

The following table accomplishes the first one of these goals in straightforward stages, by listing a set of six successive transpositions, all true to the systemic principle commanding absolute immutability. ${ }^{36}$ As we go from top to bottom, we transpose up by fourths or down by fifths. Row № 0 is occupied by the initial focal spondeiac hexachord itself. Rows № 0 and № 1, taken as a pair, fashion the full inner core -or the primary diapason / octave set- of the two solmisations under discussion. Each addition of an extra row up or down contributes fresh alterations and introduces novel modal possibilities. Of course, one can proceed in either direction for as far as one sees fit. But the author contends that all these six rows, taken jointly, very nearly exhaust the sum total of the actual tonal and modal needs in the domains of Byzantine chant and Islamic art music; readers are encouraged to check the validity of this contention for themselves.

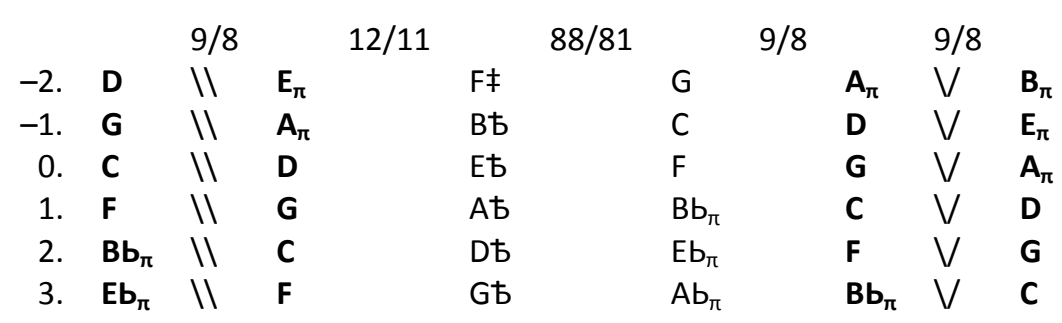

The rest is attended to in the three Appendices. Appendix 1 lists the key tonal structures of Byzantine ecclesiastical music as codified in principle in its four model bilobed scales, in accordance with the systemic tuning model analyzed and pursued throughout the present text. Appendix 2 gives a rather exhaustive list of the basic modal cells for Islamic music in the same spirit. Appendix 3, practical goal of the present paper, lays out a complete corresponding systemic fingering chart, applicable to standard F treble (alto) and C descant (soprano) recorders.

\footnotetext{
${ }^{36}$ The thesis put forth here is that all alterations cited are products of transposing the diatonic spondeiac hexachord, which is the only structure resulting from intervallic divisions; this fact is consistent with the folk practice employing a different size of diatonic pipe for each tonality, all sounding the same, relatively. Principal fixed notes are shown in large bold face: regular script is used for secondary fluid ones. As we expand, a new type of systemic dualities emerges regarding certain notes: the same note can be principal / fixed in one transposition and secondary / fluid in another. An interesting remark: the only notes remaining solely principal and fixed throughout this setup are i. D and $A_{\pi}$, ii. $E_{\pi}$ and $B_{\pi}$.
} 


\section{Conclusions}

In many ways, the inner workings and historical backgrounds of Byzantine (ecclesiastical) and Islamic art music often appear to the Western-trained musician and musicologist as idiomatic, quaint and cryptic. Endless disagreements of specialized musicologists and ethnomusicologists regarding the theoretical foundations of these two musics have been kindling this climate in their own ways. By applying a rigid systemic methodology, the present paper sincerely hopes to contribute towards the promotion of a better understanding of the systems in question as functional and historical organisms. Going even further, it aspires at shedding a different light on mutual elements and perhaps converging ancestral origins. It may be no coincidence that the structural mould, identified here as a spondeiac hexachord, affords the basic scales of both Byzantine and Islamic music. In both theory and practice, the scales of Ëchos Prōtos (= first) and maqām bayātī and Persian dastgā šur not only sound exactly like one other, according to every scholar and musician, but also come out in their Europeanized versions as the D mode of Western church music.

Going on from there, the present paper is indicating the English recorder as a practical material bridge and is furnishing the appropriate fingering chart in Appendix 3. To anyone playing the recorder, this fingering chart, taken systemically, will certainly seem workable in the context proposed, and that is true about extra fingerings meant for non-European structures as well. Trying out the basic Ëchoi, maqāmat and tunes by this fingering chart is a thoroughly simple matter, in fact simpler than what is demanded for many a European scale. Half-fingerings have been avoided to the fullest extent possible, but that was not always feasible; an inevitable few had to stay in.

The fingering scheme is also practicable on sopranino and tenor recorders, except for the sub-register of the bottom couple of tones which is prohibitive for the keyed tenor recorder and hard to finger and intone in fast passages for the others; but that is equally true of European compositions to a certain extent. Also, some of the more remote and elaborate accidentals are harder to play; but the É choi, dastgās and maqāmat requiring those accidentals are so advanced that, by the time one ventures to play them, one is most likely to have developed an adequately specialized virtuoso technique; in any case, technical demands posed by the recorder are noticeably more comfortable than those needed for the nāy.

Going on into a more painful subject, a growing awareness of the English recorder's propriety for these two musical cultures and genres may erect a barrier against the ongoing mutilation of the special character of these musics, as effected on a "modernizing" procrustean bed of "European" intonations, as it were. In the best cases, certain Western instruments have been known to adjust to the music that they are supposed to play, and have often developed new admirable idiomatic techniques. That has happened with the clarinet or the violoncello for instance. In any case, instruments are supposed to play structures, not change them. The English recorder has a supreme potential for serving a rôle that is preservative rather than erosive. A most convenient instrument, it is made industrially in a stunning variety of price ranges, the less expensive models being accessible to all. Furthermore, it is used in music education par excellence. ${ }^{37}$

A crucial point has been saved for last. As has been shown throughout the text, and as will become even more apparent upon inspecting the fingering chart, for systemic English fingerings to sound currently holding concert pitches $\left(\mathrm{A}_{\pi}\right.$ : from 440 to $448 \mathrm{~Hz}$ ) according to the universal standardized correspondences of both these musics, $\mathrm{F}$ and $\mathrm{Bb}_{\pi}$ recorders would be required. Such instruments as the latter are not currently made. Systemic fingerings, as applied on recorders in C, sound these solmisations one full epogdoos tone higher than the widespread applicable pure-theoretical standard.

\footnotetext{
${ }^{37}$ Some of the leading music training systems active in various countries throughout Europe and elsewhere, especially those aimed at youngsters, employ the recorder extensively. These systems typically make a point of including pieces of national traditional / ethnic repertoires. In so doing, they distort soft diatonic genres into their compromised Western-intoned travesties, a fact regarded as inescapable because of the recorder's Western provenance. Those operating in Greece have so far been instrumental in "mistuning the ears" of generations of Greek children regarding their ethnic and religious music. This disastrous factor undermines understanding the repertoire and helping it survive. An awareness of the recorder's "other" possibilities, as presented in this paper, can be irreplaceable in helping to achieve the exact opposite by the very same means; these systems can now turn into poles of protection of cultural heritage. In occasional discussions between the author and music educators and prominent church cantors in Greece, the case argued herein strikes all as an unexpected surprise, nothing short of a dream come true. Presumably, the same feeling is expected to be shared throughout the Near and Middle East and North Africa, if and when awareness of the potential maintained here should arise.
} 
We trust that, if the case presented in this paper is found convincing, it is quite likely that someone in the industry may realize the large potentials of an anticipated demand and decide to give it a try. Current treble and sopranino instruments are perfectly fit for the cause. So, this paper wishes to close by making an appeal to all concerned for designing and producing two new sizes of English recorders in $\mathbf{B} \mathbf{b}_{(\boldsymbol{\pi})}$, conceived as analogues of the current descant and tenor instruments in C.

For purposes of identification and distinction, names must be devised for these two prospective recorders. Following a trial-and-error examination of terminology, as subject to a number of crucial musictheoretical considerations, the author is driven to the following proposal: that they be named, respectively, sopranone and tenorone.

\section{APPENDIX 1. BYZANTINE ECCLESIASTICAL SCALES}

The annotated, tuned list given below is a strict systemization of standard Byzantine church scales and modes as they emerge from an exhaustive overview of the entire relevant literature, contingent on the considerations developed in this paper. ${ }^{38}$ The names of the notes adhere to the Chrysanthene reform, currently adopted officially by Greek and Cypriot cantors and the Greek Orthodox Patriarchates and Archbishoprics, in replacement of medieval Byzantine formulaic names [ananes, neanes, aneanes or nana, (h)agia, necheanes, aanes, neagie.$^{39}$ Chrysanthus draws on the Greek alphabet; essentially his $[\pi \alpha, \beta 8, \gamma \alpha, \delta \mathrm{l}, \kappa \varepsilon, \zeta \omega, v \eta]$ mean $[\alpha$, $\beta, \gamma, \delta, \varepsilon, \zeta, \eta]$.

A plethora of diverse accidental marks prescribing various functions have been employed both in medieval and in later manuscripts and texts. All those marks reflect an intricate historical palimpsest of chroae (colorations), martyriae (signatures) and phthorae (alterations, modulations). A combination of all the older systems is not possible to cope with, which is why Chrysanthus launched his reform in the first place.

In this text we have made use of a selection of special tradition- and literature-derived accidentals, chosen and applied through rationales way beyond the present scope. All our simple accidentals here denote basic alterations by enharmonic dieses (and hypheses), i.e., raising and lowering roughly by quarter-tones. Our half-sharps and half-flats come in dual sizes and shapes, and our "double half-sharps and half-flats" come in a single shape each, for the specific systemic and music-theoretical reasons exposed and discussed in sect. 5, f; proceeding, then, along the same set of reasons:

- half-sharps: H, 3; Pythagorean double half-sharp or full sharp (by an apotomē): 5;

- half-flats: $d$, ?; Pythagorean double half-flat or full flat (by an apotomē): ?.

Attractions and repulsions are marked. The four principal scales do not include certain rarer or more obscure chroic and phthoric variants. A fair visual correspondence has been kept between the spacing of the figures below and the actual logarithmic / perceptual step widths.

\section{THE SCALES}

a. "Soft" or "natural" diatonic scale: Échoi Prōtos and Plagios Prōtos (on D and $\mathrm{A}_{\pi}$ according to the present systemic approach), Barys Diatonicos (on $B \hbar$, with a -repelled- $\mathrm{Bb}_{\pi}$ leading tone, ${ }^{40}$ detouring via attached italicized chromatic "trichord" G to Bt), Tetartos Hagia (on G; it often uses $B_{\pi}$ in lieu of $A_{\pi}$, employing the same "trichord", especially in decisive ascending motion, and/or assumes a -repelled- leading tone Gb,

\footnotetext{
${ }^{38}$ Besides single sources like Chrysanthus, 1832 and many others, an excellent comprehensive -and comprehensible- account can be found in Desby, 1974. Also check Spyrakis.

${ }^{39}$ Desby, p. 132.

${ }^{40}$ This systemic Pythagorean $\mathrm{Bb}_{\pi}$ leading tone is invariably seen and described as some sort of "high-bent $A \#_{\pi}$ ".
} 
detouring via the other chromatic "trichord", Eち to G), Deuteros Diatonicos Tetraphōnos (on E⿱) and "Ë$c h o s$ O" / Antiplagios Tetartos (on C). ${ }^{41}$

\begin{tabular}{|c|c|c|c|c|c|c|c|c|c|}
\hline MK $62 / 3$ & \multicolumn{2}{|c|}{$61 / 3$} & 9 & & 9 & \multicolumn{2}{|c|}{$61 / 3$} & 9 & \\
\hline sx $\quad 77$ & \multicolumn{2}{|c|}{73} & 104 & & 104 & 77 & 73 & 104 & \\
\hline cts 151 & \multicolumn{2}{|c|}{143} & 204 & & 204 & 151 & 143 & 204 & \\
\hline $12 / 11$ & \multicolumn{2}{|c|}{$88 / 81$} & $9 / 8$ & & $9 / 8$ & $12 / 11$ & 81 & $9 / 8$ & \\
\hline D & $E t \uparrow$ & $\mathrm{F}$ & & G & & $B \leftarrow \uparrow$ & C & & $D$ \\
\hline \multirow[t]{3}{*}{$\pi \alpha$} & B. & $y \alpha$ & & . & & $\zeta \omega \underline{1}$ & vn & & $\pi \alpha$ \\
\hline & $\begin{array}{l}E b \uparrow \\
B_{s} \uparrow\end{array}$ & & $\begin{array}{l}{[F \neq \uparrow]} \\
{[\gamma \alpha S \downarrow]}\end{array}$ & $\begin{array}{l}G \\
\delta l\end{array}$ & & $\begin{array}{l}B b_{\pi} \downarrow B \delta(\uparrow \\
\zeta \omega ? \downarrow \zeta \omega(\uparrow\end{array}$ & & $\begin{array}{l}{[C \neq \downarrow]} \\
{[v n 3 \downarrow]}\end{array}$ & $\begin{array}{l}D \\
\pi \alpha\end{array}$ \\
\hline & & $9 / 8$ & $88 / 81$ & & $32 / 27$ & $729 / 704$ & $9 / 8$ & $88 / 81$ & \\
\hline$M K$ & & 9 & $61 / 3$ & & 13 & $2 \frac{2}{3}$ & 9 & $61 / 3$ & \\
\hline$s x$ & & 104 & 73 & & 150 & 27 & 104 & 73 & \\
\hline cts & & 204 & 143 & & 294 & 53 & 204 & 143 & \\
\hline
\end{tabular}

b. "Soft chromatic" scale: ${ }^{42} \bar{E} c h o s$ Deuteros Legetos (from E⿱ , registered to C and G).

\begin{tabular}{|c|c|c|c|c|c|c|}
\hline MK $6^{2} / 3$ & 9 & $61 / 3$ & 9 & $62 / 3$ & 9 & $61 / 3$ \\
\hline 77 & 104 & 73 & 104 & 77 & 104 & 73 \\
\hline cts 151 & 204 & 143 & 204 & 151 & 204 & 143 \\
\hline $12 / 11$ & $9 / 8$ & $88 / 81$ & $9 / 8$ & $12 / 11$ & $9 / 8$ & $88 / 8$ \\
\hline C & Dち $\downarrow$ & Et $\uparrow$ & $\mathrm{F}$ & G & Aち $\downarrow$ & $\mathrm{BD} \uparrow$ \\
\hline
\end{tabular}

c. "Hard" / "syntonic" / Pythagorean / "ditonic" diatonic scale: Ëchoi "O sclèros / syntonos" diatonic (on C) / Nana (on $F$ and $B b \pi$, current intonations for Échoi i. Tritos and ii. Antiplagios Tritos or Enharmonios tou Bareos). ${ }^{43}$ Also Ëchoi "sclēroi / syntonoi": Prōtos (on D), Deuteros Nenanō (on $\mathrm{E}_{\pi}$ ).

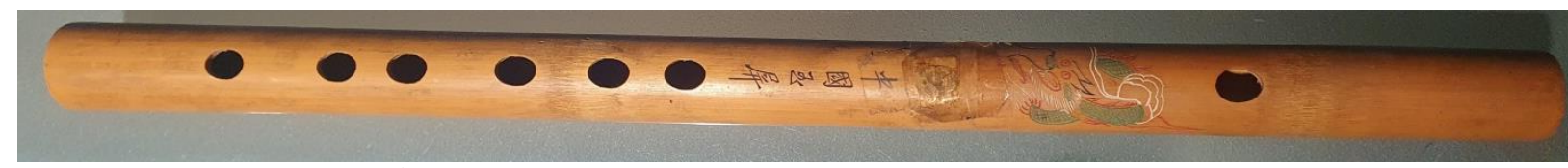

Figure 5: Traditional hard / syntonic diatonic flute in strictly Pythagorean intonation. Shifted-type side drilling; from China.

\begin{tabular}{|c|c|c|c|c|c|c|c|c|c|c|c|c|}
\hline MK & 9 & & 9 & \multicolumn{2}{|c|}{4} & 9 & & 9 & & 9 & \multicolumn{2}{|l|}{4} \\
\hline sx & 104 & & 104 & \multicolumn{2}{|c|}{46} & 104 & & 104 & & 104 & \multicolumn{2}{|c|}{46} \\
\hline cts & 204 & & 204 & \multicolumn{2}{|c|}{90} & 204 & & 204 & & 204 & \multicolumn{2}{|c|}{90} \\
\hline & $9 / 8$ & & $9 / 8$ & \multicolumn{2}{|c|}{$256 / 243$} & $9 / 8$ & & $9 / 8$ & & $9 / 8$ & \multicolumn{2}{|c|}{$256 / 243$} \\
\hline C & & D & & $\mathrm{E}_{\pi}$ & $\mathrm{F}$ & & G & & $A_{\pi}$ & & $\mathrm{B}_{\pi}$ & C \\
\hline$(F$ & & G & & $A_{\pi}$ & $\mathrm{Bb}_{\pi}$ & & C & & D & & $\mathrm{E}_{\pi}$ & F) \\
\hline$\left(\mathrm{Bb}_{\pi}\right.$ & & C & & D & $\mathrm{Eb}_{\pi}$ & & $F$ & & G & & $A_{\pi}$ & $\left.\mathrm{Bb}_{\pi}\right)$ \\
\hline$v \eta$ & & $\pi \alpha$ & & BrH & $\gamma \alpha$ & & $\delta \mathrm{\imath}$ & & $\kappa \varepsilon$ & & $\zeta \omega \mathrm{H}$ & $v \eta$ \\
\hline$(\gamma \alpha$ & & $\delta \mathrm{l}$ & & K $\varepsilon$ & $\zeta \omega ?$ & & vn & & $\pi \alpha$ & & $\mathrm{BsH}$ & $\gamma \alpha)$ \\
\hline$(\zeta \omega ?$ & & $v \eta$ & & $\pi \alpha$ & $\beta 8 ?$ & & $\gamma \alpha$ & & $\delta \mathrm{l}$ & & $\kappa \varepsilon$ & $\zeta \omega ?)$ \\
\hline
\end{tabular}

\footnotetext{
${ }^{41}$ In his intended radical definitive ultra-consistent "Fourth Reform", the author always and only calls plagios / plagalis a modal structure rooted one syllaba / perfect fourth lower or one dioxeia / perfect fifth higher. In the opposite case, regarding a modal structure rooted one dioxeia / perfect fifth lower or one syllaba / perfect fourth higher, the author coins and employs the term antiplagios. In other words, plagios shall consistently stand for dominant and antiplagios shall stand for subdominant.

${ }^{42}$ Systemically this is not a chromatic mode at all; it is a diatonic variant, chromaticized in practice by extensive idiomatic bending.

${ }^{43}$ Often this scale, which is a pure Pythagorean F major, is seen in theory books extending down by an extra "trichord" to D / $\pi \alpha$. That is because the Échos makes frequent use of a principle of "mesotēs" (a "trichord" affixed below the bass), functionally tantamount to the effect of a relative minor (on $D$ ).
} 
d. "Hard chromatic" scale: Ēchos Deuteros Chrōmaticos Nenanō : its original systemic position at $\mathrm{E}_{\pi}$ and its transposition one whole tone lower to D, currently incumbent as "Plagios Deuteros". Strong set repulsions

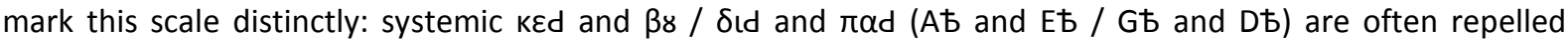
considerably lower. ${ }^{44}$

\begin{tabular}{|c|c|c|c|c|c|c|c|c|}
\hline \multicolumn{2}{|c|}{ MK 4} & $15 \% / 3$ & $21 / 3$ & 9 & \multicolumn{2}{|c|}{4} & $15 \% / 3$ & $21 / 3$ \\
\hline \multicolumn{2}{|c|}{ sx 46} & 181 & 27 & 104 & \multicolumn{2}{|c|}{46} & 181 & 27 \\
\hline \multicolumn{2}{|c|}{ cts 90} & 355 & 53 & 204 & \multicolumn{2}{|c|}{90} & 355 & 53 \\
\hline \multicolumn{2}{|c|}{$256 / 243$} & $27 / 22$ & $33 / 32$ & $9 / 8$ & \multicolumn{2}{|c|}{$256 / 243$} & $27 / 22$ & $33 / 32$ \\
\hline$\left[E_{\pi}\right.$ & $\mathrm{F}$ & & $A \hbar \downarrow A_{\pi}$ & & $\mathrm{B}_{\pi}$ & $\mathrm{C}$ & & $\left.E \hbar \downarrow E_{\pi}\right]$ \\
\hline D & $\mathrm{Eb}_{\pi}$ & & $G ち \downarrow G$ & & $A_{\pi}$ & $\mathrm{Bb}_{\pi}$ & & $D ち \downarrow D$ \\
\hline$[\beta ४ \mathrm{H}$ & $\gamma \alpha$ & & 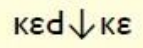 & & $\zeta \omega \mathrm{H}$ & $v \eta$ & & $\beta \triangleleft \downarrow \beta ४ \mathrm{H}]$ \\
\hline$\pi \alpha$ & $\beta x ?$ & & $\delta \mathrm{td} \downarrow \delta \mathrm{\iota}$ & & 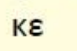 & $\zeta \omega ?$ & & $\pi \alpha d \downarrow \pi \alpha$ \\
\hline
\end{tabular}

\section{APPENDIX 2. BASIC MODAL CELLS / AJNĀS OF ISLAMIC MUSIC}

The selection of basic Islamic modal cells / ajnās ("trichords", tetrachords and pentachords) listed below has been compiled by drawing upon a variety of sources. ${ }^{45}$ The chief concern in this attempt has been to highlight the historic nucleus of the classical Islamic school as lucidly as possible. Thus, the list focuses on the most common cells reported by the majority of authors from all Islam; yet it has included a few characteristic cases found in isolated sources, whereas it has excluded certain acknowledged "modernisms". No visual correspondence will be observed here.

The tonal positioning of cells is standard in most cases. Most transpositions have been skipped. However, a limited number are included, as sometimes practice has mutated a would-be transposition towards another intonation, as resulting from altered bending patterns and from tuning compromises such as those mentioned in footn. 22. This is true of hūsāynī (a3) and bayātī (b4). A very few cells have been transposed from a currently standard tonic to another one, if this shift may help clarify a bond to a specific pitch, and thus indirectly elucidate a history of systemic generation or an "older position", especially given the inextricable ties between the complex issues of tonal positioning and pitch nomenclature. In specific instances we have even proceeded to splitting an established jins (singular of ajnās) into two systemically separate versions, a harder and a softer one, positioned accordingly (esp. the different tonalities and shades of hejāz and sabā).

The nomenclature given here strives to achieve a balance between fidelity to a Persian prototype and differences found in the Arabic and Ottoman versions. Terminologies of pitch are a valuable source of information on the history of Islamic solmisation, on its gradual development into a palimpsest and on its temporal and regional variations.

Sometimes, notes lying apart by a diapason / octave do not bear the same names. Wherever they do, practice has attached a qualifying term for specifying register. Typically, this term names a deeper or higher oud string, added at some particular stage in the history of the instrument in order to expand its range. Ušayrān, for instance, meaning baritone, is applied to the hūsāynī and ajām directly below the focal cell to

\footnotetext{
${ }^{44}$ They, too, are invariably called and thought of as "high-bent F\# and C\#". The author reckons that these repulsions are essentially attributable to a long addictive exposure to the nāy's own compromised / theoretically mistuned "F\#" / "middle hejāz" (cf. sect. 7 and footn. 31). This hypothesis probably affords the most obviously decisive argument in favour of the English recorder vs. the nāy.

${ }^{45}$ A basic codification of the Persian quarter-tone solmisation is presented and discussed in sect. III (2) of the article by Chabrier and others on the "Oûd" in the Encyclopaedia of Islam (see Ref. [5]). The author originally found the standard Arab list as furnished in Parfitt, Ref. [24b]; article "Persian Traditional Music" in Wikipedia can also be consulted for the basics (see Ref. [32]). The official Ottoman / Turkish nomenclature, which is transposed, can be found in a variety of sources, as in Parfitt, Ref. [24c], or in Yılmaz, p. 41. The reader must be warned that, ever since a reform in the early $20^{\text {th }}$ century, Turkish sources have been printing a substantially different version of tunings of notes, lists of accidentals and accounts of their functions. The system developed in this paper is much more akin to the older sources -i.e., to those until the conclusion of the $19^{\text {th }}$ century-, and seems to reflect actual Turkish musical practice a trifle more faithfully. Practically focused methodical Ref. [31] has also been consulted regularly. Last but not least, the reader is urged to visit the excellent, informed, methodical and thorough website posted by Maqam World (see Ref. [20]).
} 
indicate that those are $\mathrm{A}_{\pi}$ and $\mathrm{Bb}_{\pi}$ "in the bottom octave". ${ }^{46}$ In our list below, we annotate such differences of an octave with outline arrows: î (upper register / octave) and $\sqrt{ }$ (bottom register / octave). Special names, adopted in this text, are used in Arab music for notes of an overlying upper register; thus buzurg, māhūrān and sahm are Arabic names for upper segā, čahārgā and nāwa. As examples of other notable differences, let us mention note māhūr, which Persians call nāhuft, or the great variation in names of modes or cells.

In their evolution, Islamic musical schools have reformed and diverted their systems and intonations, especially in view of geographical and political separation, fragmentation or isolation, and of the intake of different theoretical formulations and musical influences. This is manifest in the musics of the Maghreb (NW Africa) and of Turkey. Changes have been accelerated by generalization and institutionalization of two reforms in particular: Meshaqa's quarter-tone scale amongst the Arabs, and the -Westernizing- official Ottoman reform in the beginning of $20^{\text {th }}$ century. Both, but especially the former, have launched an overwhelming impetus for transposing. As a result, solmisations have come to be regarded more as products of internal tonal subdivisions, with modalities arising as combinations of notes thus produced, rather than as outcomes of historical processes that have later been fitted to a posterior scheme. This is obviously not how the system could possibly have come about and evolved through time.

Perhaps there are very real practical necessities and technical facilitations upholding this notion. In whichever case, one direct outcome has been a perception of tones as rightful entities divisible into segments; the entire in-between area typically preserves its historical name, bestowed upon the middle subdivision (the "semitone"), the other two sharing the same name with the addition of adjectives: dik or tik for the subdivision above and nim for the one below. Whole ajnās have been moved to new roots. A note that has traditionally been tuned "too low" may now be reinstalled from its systemic position to a lower adjacent one, which probably didn't even exist earlier.

This may well be the case with pentachord huzām (e1). It is conceivable that originally this was a mere enunciation of a systemic araq on segā ([Et, F, G, A $\bar{b} \bigvee \mathrm{B} \hbar])$ (b1), a structure that has to bend its boundaries jointly (e.g. [Eち个, F, G, $A \hbar \uparrow \bigvee B \hbar \uparrow]$ ). An emancipated chromaticized shading of $A \hbar$, especially one

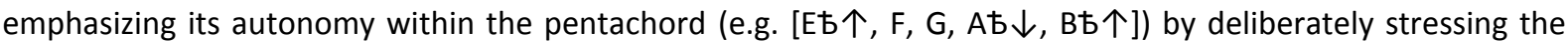
difference from a straight araq, could well be reinterpreted as something else and slide into being rewritten as $\left[E \hbar, F, G, A b_{\pi}, B \hbar\right]$, as tends to be currently done.

On the other hand, there are also alternative bendings of the same note not marked in the score, but relying on oral tradition and practical training; for instance, it is often pointed out that the segā (E⿱亠䒑)) in maqām rast (c3) has a slightly higher tuning than the segā in maqām bayātī (d4). ${ }^{47}$

For these and other relevant reasons, certain definite rigorous choices have been necessitated in this paper, differentiating some of its particulars in contrast to what one will find in the literature. In the subsequent list and fingering chart, positions of notes and terminology will be kept strictly systemic and no bendings will be marked. Names of in-between notes will be granted to the systemic prototype and, in the only two cases where there are dualities, i.e., concerning hejāz and hisar, i. the name shall be held by the systemically anterior note, ii. the sharper or flatter systemic note in the same neighbourhood shall be annotated with $\mathrm{a}^{\wedge}$ and $\mathrm{v}$, respectively. One ought to bear in mind that the triplet of $[\wedge$, nothing, $\mathrm{v}]$ IN NO WAY corresponds to the common [dik, nothing, nim] practice. ${ }^{48}$ Then, in the fingering chart of Appendix 3 , spaces reserved for tunings not corresponding to systemic pitches will be left vacant.

\footnotetext{
${ }^{46}$ Arabs can refer to the bottom A as simply ušayrān, name of the particular open string of the oud.

${ }^{47}$ Cf. Maqam World, Ref. [20], sub-page "The Arabic maqam".

${ }^{48}$ For example, the two compromise notes habitually called "hejāz", F\# and, provisionally, Gb, are not generated anywhere in the system. By our analysis, they serve as surrogates for both a low-bent Gち (our ^ hejāz, Isl. "nim hejāz") and a high-bent F‡ (our hejāz, Isl. "dik hejāz") (cf. nāy, fingering vi).
} 
THE AJNĀS

a. ON HŪSĀYNİ UŠAYRĀN (BARITONE $\mathrm{A}_{\pi}$ )

a1. hard / "zirgula hejāz" tetrachord

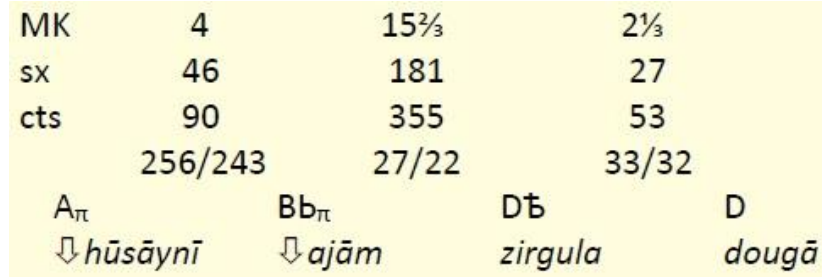

a2. sabo "tetrachord" / hexachord

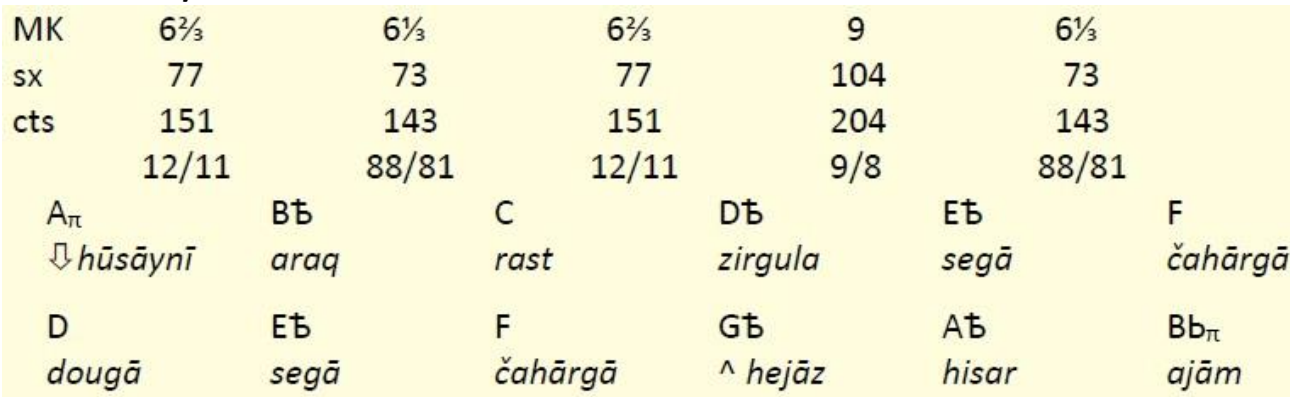

a3. hūsāynī tetrachord

\begin{tabular}{|c|c|c|c|c|c|c|}
\hline MK & $6^{2} / 3$ & & $61 / 3$ & & 9 & \\
\hline$s x$ & 77 & & 73 & & 104 & \\
\hline \multirow[t]{2}{*}{ cts } & 151 & & 143 & & 204 & \\
\hline & $12 / 11$ & & $88 / 81$ & & $9 / 8$ & \\
\hline $\begin{array}{l}A_{\pi} \\
\text { rl }\end{array}$ & $\bar{a} y n i ̄$ & $\begin{array}{l}\mathrm{Bt} \\
\text { araq }\end{array}$ & & $\begin{array}{l}\mathrm{C} \\
\text { rast }\end{array}$ & & $\begin{array}{l}\text { D } \\
\text { dougā }\end{array}$ \\
\hline
\end{tabular}

bb. ON AJĀM UŠAYRĀN (BARITONE Bb ${ }_{\pi}$ )

bb1. ajām "trichord"

$\begin{array}{lcccc}\text { MK } & 9 & & 9 & \\ \text { sX } & 104 & & 104 & \\ \text { cts } & 204 & & 204 & \\ & 9 / 8 & & 9 / 8 & \\ \text { Bb } \pi & & \text { C } & & \text { D } \\ \text { najām } & \text { rast } & & \text { douga }\end{array}$

b. ON ARAQ (/ SEGĀ) (B⿱ / E⿱一)

b1. segā "trichord"

\begin{tabular}{|c|c|c|c|}
\hline MK & $61 / 3$ & 9 & \\
\hline$s x$ & 73 & 104 & \\
\hline \multirow[t]{2}{*}{ cts } & 143 & 204 & \\
\hline & $88 / 81$ & $9 / 8$ & \\
\hline Bt & & C & D \\
\hline araq & & rast & dougā \\
\hline Et & & $F$ & G \\
\hline segā & & čahārgā & nāwa \\
\hline
\end{tabular}


b2. araq tetrachord

\begin{tabular}{|c|c|c|c|c|}
\hline MK & $61 / 3$ & 9 & $62 / 3$ & \\
\hline$s x$ & 73 & 104 & 77 & \\
\hline \multirow[t]{2}{*}{ cts } & 143 & 204 & 151 & \\
\hline & $88 / 81$ & $9 / 8$ & $12 / 11$ & \\
\hline Bt & & C & $D$ & Et \\
\hline araq & & rast & dougā & $\operatorname{seg} \bar{a}$ \\
\hline Et & & $F$ & G & $A \hbar$ \\
\hline segā & & čahārgā & nāwa & hisar \\
\hline
\end{tabular}

b3. hard musta'ār "trichord"

\begin{tabular}{|c|c|c|c|}
\hline MK & $152 / 3$ & \multicolumn{2}{|c|}{$21 / 3$} \\
\hline$s x$ & 181 & \multicolumn{2}{|c|}{27} \\
\hline cts & 355 & \multicolumn{2}{|c|}{53} \\
\hline & $27 / 22$ & \multicolumn{2}{|c|}{$33 / 32$} \\
\hline Bt & & Dt & $D$ \\
\hline araq & & zirgula & dougā \\
\hline Et & & Gt & G \\
\hline segā & & $\wedge$ hejāz & nāwa \\
\hline
\end{tabular}

c. ON RAST (C)

c1. zanjarān tetrachord / pentachord

\begin{tabular}{|c|c|c|c|c|c|c|}
\hline MK & $62 / 3$ & 9 & & $61 / 3$ & 9 & \\
\hline$s x$ & 77 & 104 & & 73 & 104 & \\
\hline \multirow[t]{2}{*}{ cts } & 143 & 204 & & 143 & 204 & \\
\hline & $12 / 11$ & $9 / 8$ & & $88 / 81$ & $9 / 8$ & \\
\hline $\begin{array}{l}\mathrm{C} \\
\text { rast }\end{array}$ & & $\begin{array}{l}\text { Dt } \\
\text { zirgula }\end{array}$ & $\begin{array}{l}\text { Et } \\
\text { segā }\end{array}$ & & $\begin{array}{l}\mathrm{F} \quad \mathrm{V} \\
\text { čahārgāa }\end{array}$ & $\begin{array}{l}\mathrm{G} \\
n a \bar{w} w a\end{array}$ \\
\hline
\end{tabular}

c2. nahāwand tetrachord / pentachord

\begin{tabular}{|c|c|c|c|c|c|c|}
\hline MK & 9 & 4 & & 9 & 9 & \\
\hline$s x$ & 104 & 46 & & 104 & 104 & \\
\hline \multirow[t]{2}{*}{ cts } & 204 & 90 & & 204 & 204 & \\
\hline & $9 / 8$ & $256 / 243$ & & $9 / 8$ & $9 / 8$ & \\
\hline $\begin{array}{l}\mathrm{C} \\
\text { rast }\end{array}$ & & $\begin{array}{l}\text { D } \\
\text { dougā }\end{array}$ & $\begin{array}{l}\mathrm{Eb}_{\pi} \\
\text { kürd }\end{array}$ & & $\begin{array}{l}\mathrm{F} \quad \mathrm{V} \\
\text { čahārgāa }\end{array}$ & $\begin{array}{l}\text { G } \\
n a \bar{w} a\end{array}$ \\
\hline
\end{tabular}

c3. hard nāwa athar / nakriz pentachord

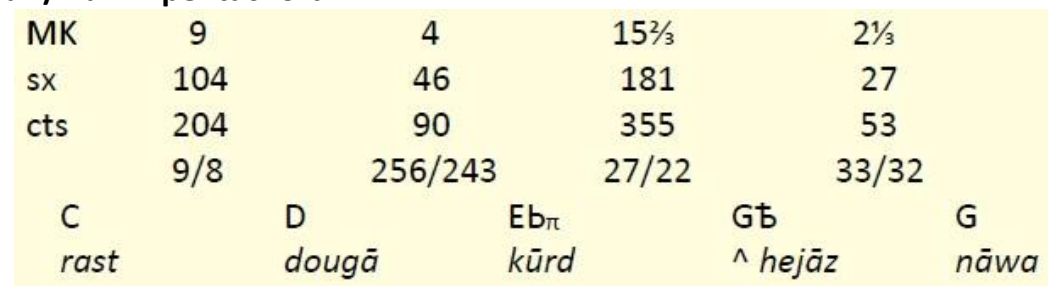


c3. rast tetrachord / pentachord

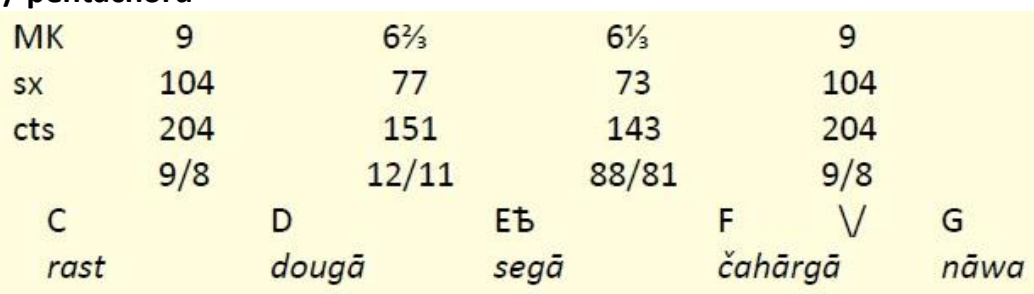

c4. soft nāwa athar / nakriz pentachord

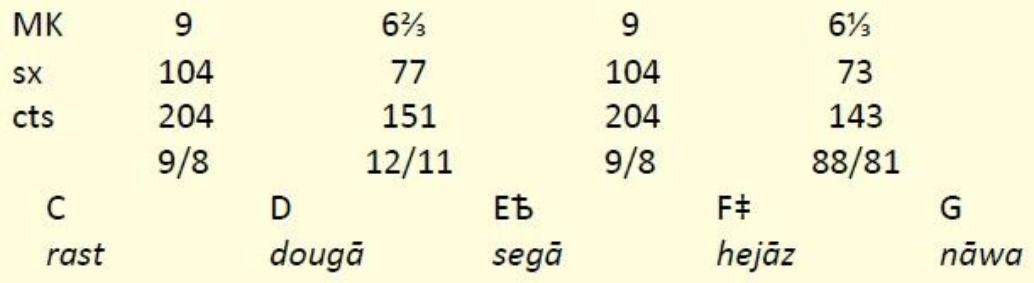

d. ON DOUGĀ (D)

d1. kūrd tetrachord / pentachord

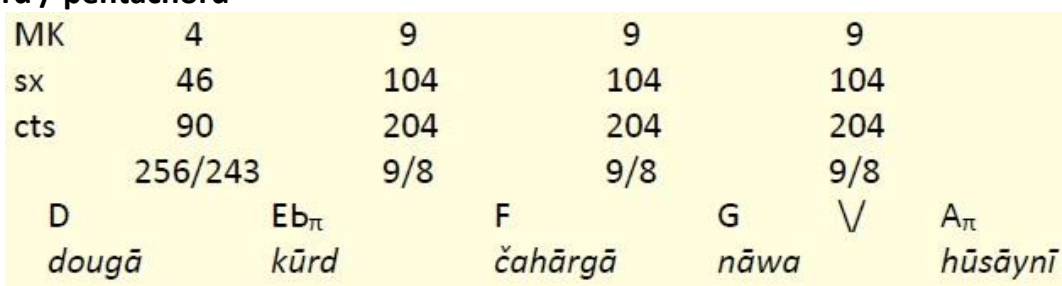

d2. hard hejāz / uzzal tetrachord / pentachord

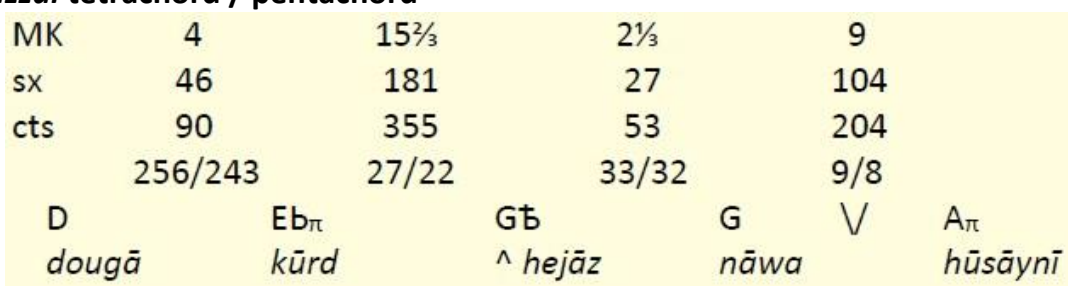

d3. $s a b \bar{a}$ "tetrachord" / pentachord

\begin{tabular}{|c|c|c|c|c|}
\hline MK & $6^{2} / 3$ & $61 / 3$ & $6^{2} / 3$ & $11 \frac{1}{3}$ \\
\hline$s x$ & 77 & 73 & 77 & 131 \\
\hline \multirow[t]{2}{*}{ cts } & 151 & 143 & 151 & 257 \\
\hline & $12 / 11$ & $88 / 81$ & $12 / 11$ & $297 / 256$ \\
\hline $\begin{array}{l}\text { D } \\
\text { dol }\end{array}$ & & $\begin{array}{l}\text { Eb } \\
\text { segā }\end{array}$ & $\begin{array}{l}\mathrm{F} \\
\text { čahārgāa }\end{array}$ & $\begin{array}{l}\text { Gb } \\
\wedge \text { hejāz }\end{array}$ \\
\hline
\end{tabular}

d4. bayātī tetrachord / pentachord

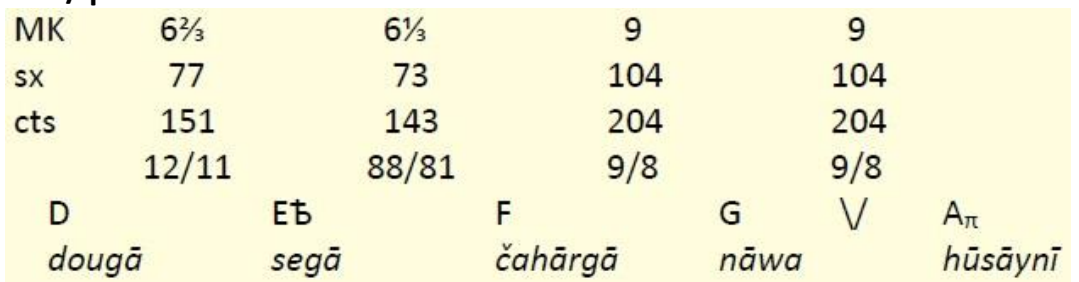


d5. busāliq tetrachord / pentachord

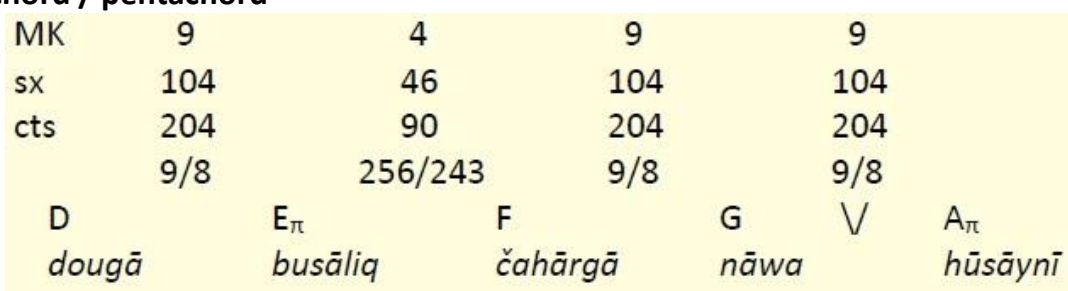

e. ON SEGĀ (Eち)

e1. huzām pentachord

\begin{tabular}{|c|c|c|c|c|}
\hline MK & $61 / 3$ & 9 & $6^{2} / 3$ & 9 \\
\hline$s x$ & 73 & 104 & 77 & 104 \\
\hline \multirow[t]{2}{*}{ cts } & 143 & 204 & 151 & 204 \\
\hline & $88 / 81$ & $9 / 8$ & $12 / 11$ & $9 / 8$ \\
\hline $\begin{array}{l}\text { Et } \\
\text { segā }\end{array}$ & & $\begin{array}{l}\text { F } \\
\text { čahärgāa }\end{array}$ & $\begin{array}{l}\text { G } \\
\text { nāwa }\end{array}$ & $\begin{array}{l}\mathrm{A} \hbar(\downarrow) \bigvee \\
\text { hisar }\end{array}$ \\
\hline
\end{tabular}

e2. segā pentachord

\begin{tabular}{|c|c|c|c|c|}
\hline MK & $61 / 3$ & 9 & 9 & $62 / 3$ \\
\hline$s x$ & 73 & 104 & 104 & 77 \\
\hline \multirow[t]{2}{*}{ cts } & 143 & 204 & 204 & 151 \\
\hline & $88 / 81$ & $9 / 8$ & $9 / 8$ & $12 / 11$ \\
\hline $\begin{array}{l}\text { Et } \\
\text { segā }\end{array}$ & & $\begin{array}{l}\mathrm{F} \\
\text { čahārgāa }\end{array}$ & $\begin{array}{l}\text { G } \\
\text { nāwa }\end{array}$ & $\begin{array}{l}\mathrm{A}_{\pi} \\
\text { hūsāynī }\end{array}$ \\
\hline
\end{tabular}

e3. soft musta'ār "trichord"

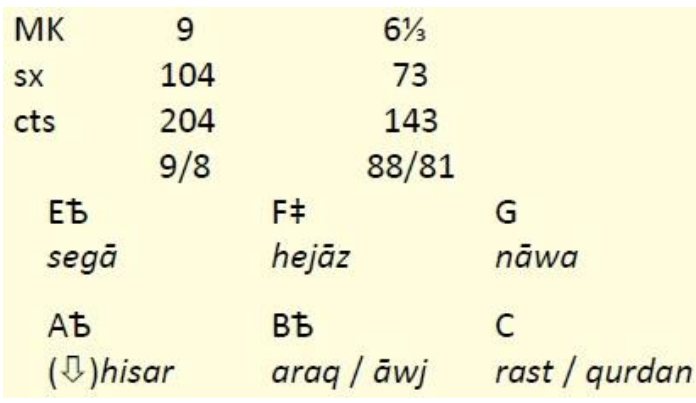

\section{f. ON ČAHĀRḠ̄ (F)}

f1. čahārgā tetrachord / pentachord

\begin{tabular}{|c|c|c|c|c|c|c|}
\hline MK & 9 & & & & 9 & \\
\hline$s x$ & 104 & & & & 104 & \\
\hline \multirow[t]{2}{*}{ cts } & 204 & & & & 204 & \\
\hline & $9 / 8$ & & 25 & & $9 / 8$ & \\
\hline \multirow{2}{*}{\multicolumn{2}{|c|}{$\begin{array}{l}\mathrm{F} \\
\text { čahārgā }\end{array}$}} & G & $A_{\pi}$ & $\mathrm{Bb}_{\pi}$ & V & C \\
\hline & & $n a \overline{w a}$ & hūsāynì & ajām & & qurdan \\
\hline \multicolumn{2}{|l|}{$C$} & D & $\mathrm{E}_{\pi}$ & & V & G \\
\hline \multicolumn{2}{|c|}{ rast } & dougā & busāliq & \multicolumn{2}{|c|}{ čahārgā } & nāwa \\
\hline \multicolumn{2}{|c|}{ G } & $A_{\pi}$ & $\mathrm{B}_{\pi}$ & C & V & $D$ \\
\hline \multicolumn{2}{|c|}{ nāwa } & hūsāyn & māhūr & \multicolumn{2}{|l|}{ qurdan } & m'hayār \\
\hline
\end{tabular}


g. ON NĀWA (G)

g1. soft hejāz tetrachord / pentachord

\begin{tabular}{|c|c|c|c|c|c|c|c|c|}
\hline MK & $62 / 3$ & & 9 & & $61 / 3$ & & 9 & \\
\hline$s x$ & 77 & & 104 & & 73 & & 104 & \\
\hline \multirow[t]{2}{*}{ cts } & 151 & & 204 & & 143 & & 204 & \\
\hline & $12 / 11$ & & $9 / 8$ & & $88 / 81$ & & $9 / 8$ & \\
\hline G & & $A \hbar$ & & $\mathrm{Bt}$ & & C & V & $D$ \\
\hline & & hisar & & $\bar{a} w j$ & & qurdan & & m'hayār \\
\hline D & & Et & & $\mathrm{F} \neq$ & & G & V & $A_{\pi}$ \\
\hline & & $\operatorname{seg} \bar{a}$ & & hejäz & & nāwa & & hūsāynì \\
\hline
\end{tabular}

APPENDIX 3.

ENGLISH RECORDER FINGERING CHARTS

FOR BYZANTINE ECCLESIASTICAL AND ISLAMIC ART MUSIC

$\begin{array}{llllll}\text { 1. } & & & & \text { i } \\ \text { 2. }\end{array}$




\begin{tabular}{|c|c|c|c|c|c|c|}
\hline 1. & vii & viii & ix & x & xi & xii \\
\hline $\begin{array}{l}2 . \\
3 . \\
4 .\end{array}$ & 8 & $\stackrel{9}{\circ}$ & 8 & 8 & 8 & \\
\hline $\begin{array}{l}5 . \\
6 . \\
7 . \\
8 .\end{array}$ & $\begin{array}{l}\bullet \\
\circ 0 \\
\bullet \bullet\end{array}$ & $\begin{array}{l}: \\
00 \\
\circ 0\end{array}$ & $\begin{array}{l}\bullet \\
0 \\
\bullet \bullet\end{array}$ & $\begin{array}{l}9 \\
0 \\
00 \\
00\end{array}$ & $\stackrel{\circ}{\bullet \bullet}$ & $\begin{array}{l}\circ \\
\bullet \\
\circ \\
\bullet \bullet\end{array}$ \\
\hline \multirow[t]{3}{*}{ syst. } & $\mathrm{Dt}$ & D & $\mathrm{Eb}_{\pi}$ & Eb & $\mathrm{E}_{\pi}$ & $\mathrm{Ft}$ \\
\hline & $\pi \alpha d$ & $\pi \alpha$ & $\beta ४ ?$ & $\beta 8$ & $\beta 8 \mathrm{H}$ & (pad) \\
\hline & zirgula & dougā & kūrd & $\operatorname{seg} \bar{a}$ & busāliq & \\
\hline \multirow[t]{3}{*}{ F trbl. } & $A \hbar$ & $A_{\pi}$ & $\mathrm{Bb}_{\pi}$ & $\mathrm{Bb}$ & $\mathrm{B}_{\pi}$ & $\mathrm{Cb}$ \\
\hline & ked & $\kappa \varepsilon$ & $\zeta \omega ?$ & $\zeta \omega$ & $\zeta \omega \mathrm{H}$ & (vnd) \\
\hline & Ihisar & そhuūsāynì & תl ajām & araq & gāwešt & \\
\hline \multirow[t]{3}{*}{ C dsc. } & Et & $E_{\pi}$ & $\mathrm{F}$ & $\mathrm{F} \neq$ & $\mathrm{F} \#_{\pi}$ & Gt \\
\hline & $\beta$ в & $\beta \triangleleft \mathrm{H}$ & $\gamma \alpha$ & pab & (pas) & Sid \\
\hline & segā & busāliq & čahārgā & hejāz & & $\wedge$ hejāz \\
\hline
\end{tabular}

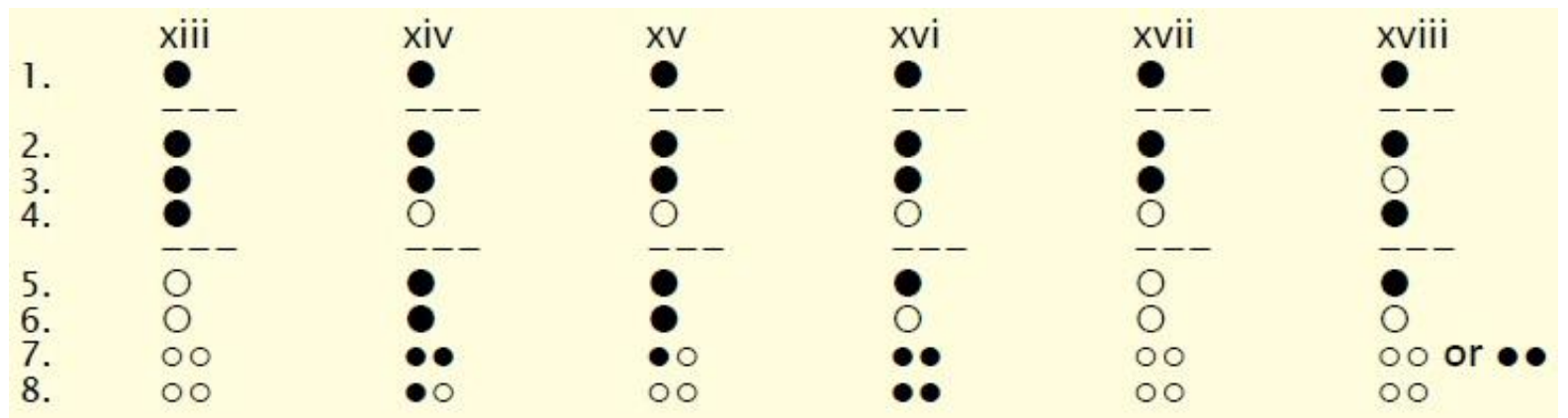

\begin{tabular}{|c|c|c|c|c|c|c|}
\hline \multirow[t]{3}{*}{ syst. } & $F$ & $\mathrm{~F} \neq$ & $\mathrm{Gb}_{\pi}$ & Gt & G & $A b_{\pi}$ \\
\hline & $\gamma \alpha$ & yab & $(\delta เ ?)$ & Std & $\delta \mathrm{l}$ & $\kappa \varepsilon ?$ \\
\hline & čahārgā & hejāz & & ${ }^{\wedge}$ hejāz & nāwa & $v$ hisar \\
\hline \multirow[t]{3}{*}{ F trbl. } & C & $C \neq$ & $\mathrm{Db}_{\pi}$ & Dt & D & $\mathrm{Eb}_{\pi}$ \\
\hline & vn & (vnל) & $(\pi \alpha 2)$ & $\pi \alpha d$ & $\pi \alpha$ & $\beta ४$ ? \\
\hline & rast & & & zirgula & dougā & kūrd \\
\hline \multirow[t]{3}{*}{ C dsc. } & G & $\mathrm{G} \neq$ & $A b_{\pi}$ & $A \hbar$ & $A_{\pi}$ & $\mathrm{Bb}_{\pi}$ \\
\hline & $\delta \mathrm{l}$ & $(\delta, \zeta)$ & $\kappa \varepsilon ?$ & kहd & $\kappa \varepsilon$ & $\zeta \omega ?$ \\
\hline & nāwa & & v hisar & hisar & hūsāynì & ajām \\
\hline
\end{tabular}




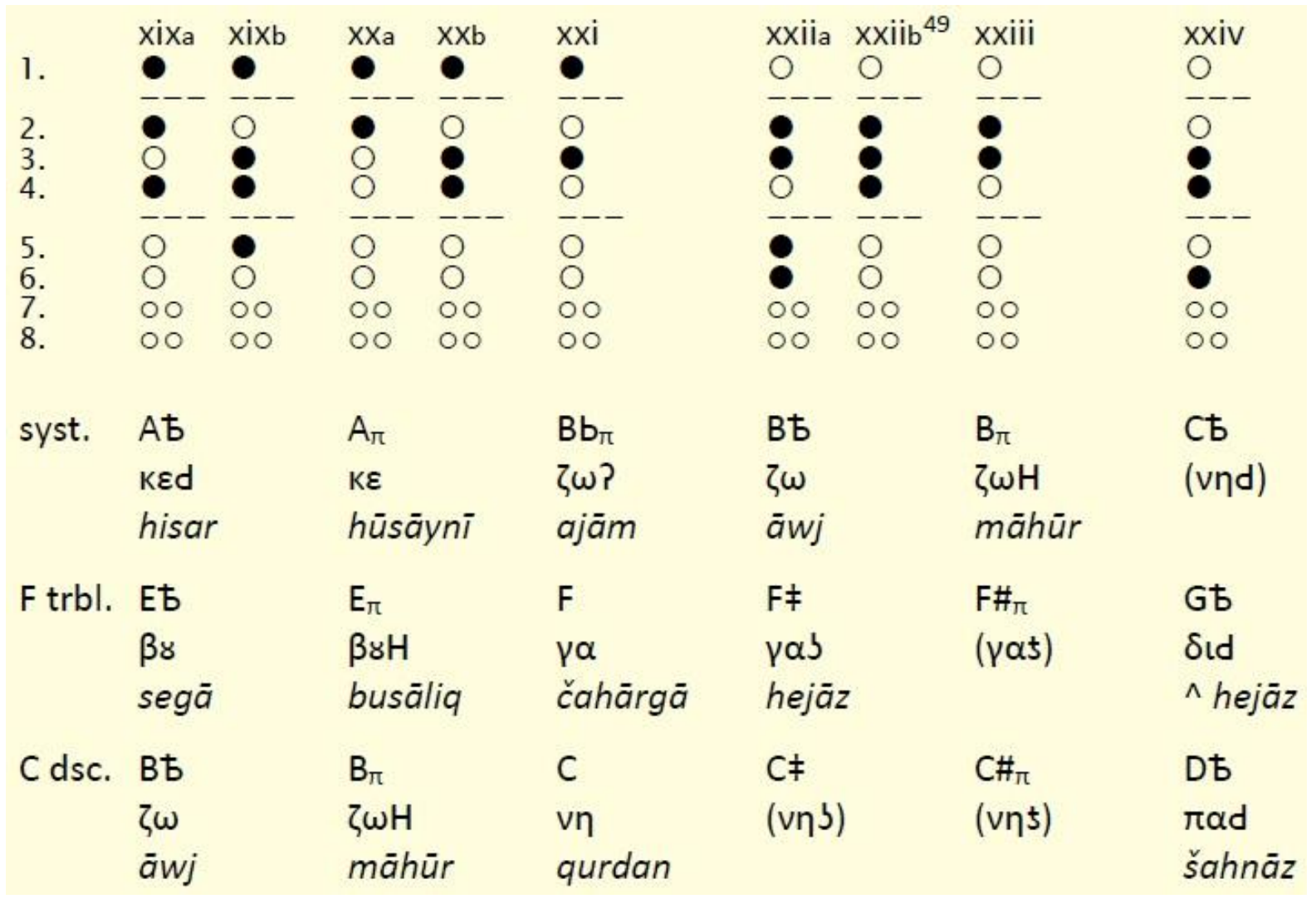
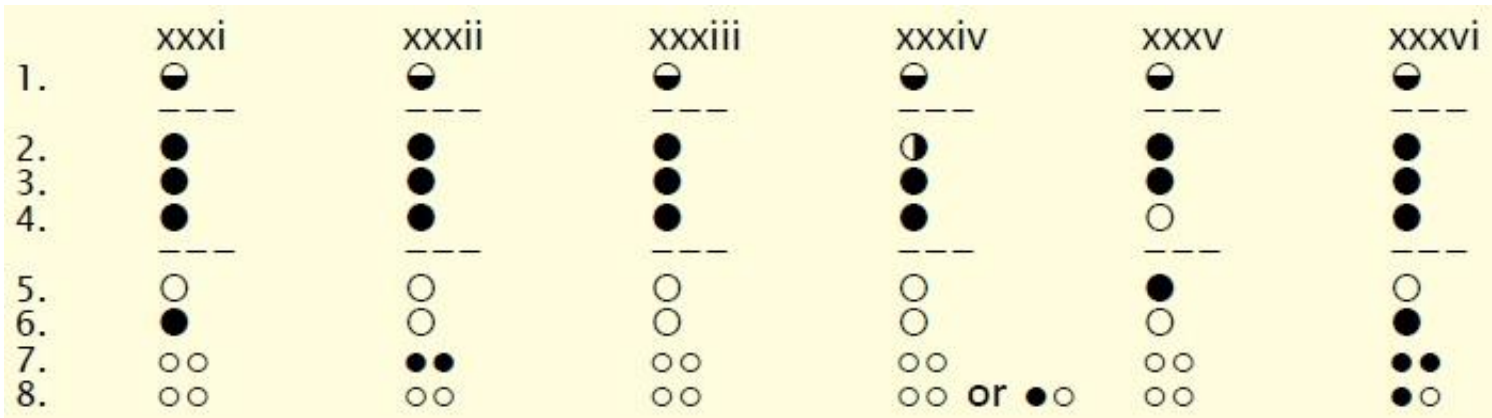
syst. $E_{\pi}$
BrH
Ft 仓ै busāliq
(rad)

F

$\mathrm{F} \neq$

$\mathrm{Gb}_{\pi}$

Gt

$\gamma \alpha$

$\gamma \alpha b$

(ठเ?)

Sid māhūrān

v̂hejāz

$\hat{\vartheta}^{\wedge} h e j a \bar{z} z$

F trbl. $B_{\pi}$

$\zeta \omega \mathrm{H}$

Cb māhūr

(vnd)

C

$C \neq$

$\mathrm{Db}_{\pi}$

Dt

vn

(vns)

$(\pi \alpha$ ?)

rad

qurdan

šahnāz

C dsc. $\quad \mathrm{F}_{\pi}$

Gt

G

$\delta \mathrm{s}$

$\widehat{\vartheta}^{\wedge} h e j a \bar{z}$

sahm

$\mathrm{G} \ddagger$

$(\delta, \zeta)$
$A b_{\pi}$

$\kappa \varepsilon$ ?

仓ิv hisar
At Ked 仓̂hisar

\footnotetext{
${ }^{49}$ Fingering xxiib is slightly flat. It is more convenient in many instances, but should be used with caution as it requires harder breathing if it is to sound in tune. However, in a descending passage which calls for a somewhat flatter intonation of the note, it may sound proper, or even be deemed preferable.
} 


\begin{tabular}{|c|c|c|c|c|c|c|}
\hline 1. & $\begin{array}{l}\text { xxxvii } \\
\ominus\end{array}$ & $\begin{array}{l}\text { xxxviii } \\
\ominus\end{array}$ & $\underset{\ominus}{x x x i x}$ & $\begin{array}{l}x l \\
\ominus\end{array}$ & $\underset{\ominus}{x l i}$ & $\underset{\ominus}{x}$ \\
\hline $\begin{array}{l}2 . \\
3 . \\
4 .\end{array}$ & 8 & 8 & $\begin{array}{l}\bullet \\
0 \\
0\end{array}$ & 8 & $\begin{array}{l}\bullet \\
0 \\
0\end{array}$ & $\begin{array}{l}0 \\
0 \\
0\end{array}$ \\
\hline $\begin{array}{l}5 . \\
6 . \\
7 . \\
8 .\end{array}$ & $\begin{array}{l}0 \\
\bigcirc \\
00 \\
00\end{array}$ & or 0 & $\begin{array}{l}0 \\
0 \\
0\end{array}$ & $\begin{array}{l}8 \\
00 \\
00\end{array}$ & $\begin{array}{l}\bullet \\
0 \\
00 \\
00\end{array}$ & $\begin{array}{l}9 \\
00 \\
00\end{array}$ \\
\hline \multirow[t]{3}{*}{ syst } & G & $\mathrm{Ab}_{\pi}$ & $A \hbar$ & $A_{\pi}$ & $\mathrm{Bb}_{\pi}$ & $B t$ \\
\hline & $\delta \mathrm{\iota}$ & $\kappa \varepsilon ?$ & ked & K $\varepsilon$ & $\zeta \omega ?$ & $\zeta \omega$ \\
\hline & sahm & 仓v hisar & 仓hisar & 仓̂ūssāynì & 仓ajām & 仓̄āwj \\
\hline \multirow[t]{3}{*}{ F trbl. } & D & $\mathrm{Eb}_{\pi}$ & Et & $\mathrm{E}_{\pi}$ & $\mathrm{F}$ & $\mathrm{F} \neq$ \\
\hline & $\pi \alpha$ & $\beta 8 ?$ & $\beta 8$ & $\beta 8 \mathrm{H}$ & $\gamma \alpha$ & pab \\
\hline & m'hayār & sunbulā & buzurg & 仓̂busāliq & māhūrān & 仓hejāz \\
\hline \multirow[t]{3}{*}{ C dsc. } & $A_{\pi}$ & $\mathrm{Bb}_{\pi}$ & Bt & $\mathrm{B}_{\pi}$ & C & $C \ddagger$ \\
\hline & 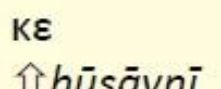 & $\zeta \omega{ }^{\prime}$ & $\zeta \omega$ & $\zeta \omega \mathrm{H}$ & $v \eta$ & $(v \eta 3)$ \\
\hline & Ưhüsāynì & 仓ajām & 仓̄āwj & 仓̀māhūr & 仓qurdan & \\
\hline
\end{tabular}

\begin{tabular}{|c|c|c|c|c|c|c|}
\hline $\begin{array}{l}1 . \\
2 . \\
3 . \\
4 .\end{array}$ & \begin{tabular}{l} 
xliii \\
$\ominus$ \\
\hdashline$\bullet$ \\
$\ominus$ \\
$\bullet$
\end{tabular} & \begin{tabular}{l} 
xliv \\
$\ominus$ \\
\hdashline 0 \\
0 \\
0
\end{tabular} & \begin{tabular}{l} 
xlv \\
$\ominus$ \\
\hdashline$\bullet$ \\
0 \\
$\bullet$
\end{tabular} & \begin{tabular}{l} 
xlvi \\
$\ominus$ \\
\hdashline$\bullet$ \\
$\bullet$ \\
$\bullet$
\end{tabular} & \begin{tabular}{l} 
xlvii \\
$\ominus$ \\
\hdashline$\bigcirc$ \\
$\bigcirc$ \\
0 \\
$\bullet$
\end{tabular} & \begin{tabular}{l} 
xlviii \\
0 \\
\hdashline 0 \\
0 \\
0
\end{tabular} \\
\hline $\begin{array}{l}5 . \\
6 . \\
7 . \\
8 .\end{array}$ & $\because$ or $\circ \circ$ & $\begin{array}{l}\bullet \\
\bullet \bullet \\
\bullet \bullet\end{array}$ & $\begin{array}{l}\bullet \\
0 \\
00\end{array}$ & $\begin{array}{l}0 \\
0 \\
00 \\
00\end{array}$ & $\begin{array}{l}0 \\
0 \\
00 \\
00\end{array}$ & $\begin{array}{l}0 \\
0 \\
00 \\
00\end{array}$ \\
\hline syst. & $\begin{array}{l}\mathrm{B}_{\pi} \\
\zeta \omega \mathrm{H} \\
\text { 仓r } m a \bar{h} h \bar{u} r\end{array}$ & $\begin{array}{l}C b \\
\text { (vnd) }\end{array}$ & $\begin{array}{l}\text { C } \\
\text { vn } \\
\text { 仓qurdan }\end{array}$ & $\begin{array}{l}\mathrm{Db}_{\pi} \\
(\pi \alpha ?)\end{array}$ & $\begin{array}{l}\text { Dt } \\
\text { rad } \\
\text { 仓̌̌ahnāz }\end{array}$ & $\begin{array}{l}\text { D } \\
\pi \alpha \\
\text { 仓 } m^{\prime} h a y a ̄ r\end{array}$ \\
\hline F trbl. & $\begin{array}{l}\mathrm{F}_{\pi} \\
(\gamma \alpha \zeta)\end{array}$ & 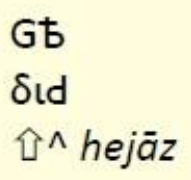 & $\begin{array}{l}\mathrm{G} \\
\delta \mathrm{L} \\
\text { sahm }\end{array}$ & $\begin{array}{l}\mathrm{Ab}_{\pi} \\
\mathrm{k} \varepsilon ? \\
\text { 仓 } \mathrm{v} \text { hisar }\end{array}$ & $\begin{array}{l}\text { Aち } \\
\text { ked } \\
\text { i hisar }\end{array}$ & $\begin{array}{l}\mathrm{A}_{\pi} \\
\kappa \varepsilon \\
\text { 仓 hüsāynì }\end{array}$ \\
\hline C dsc. & $\begin{array}{l}\mathrm{C}_{\pi} \\
(v \eta 5)\end{array}$ & $\begin{array}{l}\text { Dt } \\
\text { rad } \\
\text { 仓šahnāz }\end{array}$ & $\begin{array}{l}\text { D } \\
\pi \alpha \\
\text { 仓 } m^{\prime} h a y a \bar{r}\end{array}$ & $\begin{array}{l}\mathrm{Eb}_{\pi} \\
\beta \& ? \\
\text { 仓sunbulā }\end{array}$ & $\begin{array}{l}\text { Et } \\
\text { ßr } \\
\text { 仓ि buzurg }\end{array}$ & $\begin{array}{l}\mathrm{E}_{\pi} \\
\beta \varangle \mathrm{H} \\
\text { 仓仓 } \mathrm{v} \text { busāliq }\end{array}$ \\
\hline
\end{tabular}


All instruments pictured in the article come from the author's private collection. Original photographs by Giannis Pliagkos.

\section{REFERENCES}

Note: all websites cited were last accessed in November 2021, except № [24].

[1] Antique Sound Workshop, Ltd., 2002, "Recorder Fingering Systems: the Good, the Bad and the Ugly", accessible online at: http://www.aswltd.com/finger.htm.

[2] Aristoxenus, 1977, Harmonica Stoicheia (Harmonic Elements), vol. B, series: Ancient Harmonic Writers (Athens: Georgiades publications - Library of the Hellenes) [ $4^{\text {th }} \mathrm{C}$. BCE text in Greek].

[3] Bilitzky, Hagay, 2021, "Arabic Music Theory", website Double BassEast, accessible online at: http://doublebasseast.com/category/arabic-music-theory/

[4] Callinicos, Theodoulos, 1977-1981, Mega Theorēticon Byzantinēs Ecclēsiastikēs Mousikēs (Great Theoreticum of Byzantine Church Music) (Nicosia: n.p.) [in Greek].

[5] Chabrier J.-Cl., Dietrich A., Bosworth C.E., Farmer H.G., n.d., "Oûd”; in: Encyclopaedia of Islam, available online at: https://brill.com/view/package/eio.

[6] Chrysanthus of Madytus, Archbishop of Dyrrhachium, 1832: Theorēticon Mega tēs Mousikēs (Great Theoreticum of Music) (Trieste: Michele Weis Typography) [in Greek].

[7] Desby, Frank Harry, 1974, The Modes and Tuning in Neo-Byzantine Chant, D.M.A. thesis (University of Southern California), authorized facsimile (1982: Ann Arbor Michigan: University Microfilms International).

[8] Ellis, Alexander John, 1954: additional material (thorough revision, corrections, numerous original footnotes and appendices,) in his translation into English of: Helmholtz, Hermann L.F. von, On the Sensations of Tone as a Physiological Basis for the Theory of Music (Dover Publications, Inc., New York; reprint of the original English language publication: 1885, London, New York: Longmans, Green \& Co; original German: Die Lehre von der Tonempfindungen als Physiologische Grundlage für die Theorie der Musik, $4^{\text {th }}$ edition, 1863, Braunschweig: Vierweg \& Sohn).

[9] al-Fārābī, Abū Nasr Muhammad ibn Farūkh, Kitāb al-Mūsīqī al-Kabir. Transl. into French as Grand Traité de la Musique; in: d'Erlanger, Baron Rodolphe, 1935 / 2001, La Musique Arabe, vol. 1 (Paris: Paul Geuthner) [in French; original $11^{\text {th }}$ c. CE text in Arabic].

[10] Farmer, Henry George, 1979 ( $1^{\text {st }}$ ed. 1957), "The Music of Islam"; in: The New Oxford History of Music, vol. I: Wellesz Egon (editor), Ancient and Oriental Music, ch. XI, pp. 421-477 (Oxford University Press).

[11] Hall, Donald E., 1985, "A Systematic Evaluation of Equal Temperaments through N=612", Interface, vol. 14, pp. 61-73.

[12] Holder, William, 1967, Treatise on the Natural Grounds and Principles of Harmony, facsimile of the 1694 London edition: Broude Brothers.

[13] Jeans, Sir James, 1968, Science \& Music (London / Canada, Dover Publications Inc.; original publisher: 1937, Oxford University Press).

[14] Katsoulas, Vangelis, 2021, Turkish and Arab Makams: Music Theory for Oud, accessible online at: http://www.channelingstudio.ru/texts/Music\%20Theory\%20of\%20Makams.pdf.

[15] Lekkas, Demetrios E., 2000, "Temakhismi tis Oktavas" ("Slicings of the Octave”); in: Georgaki Anastasia (editor): $2^{\text {nd }}$ Symposium of Music Informatics, Proceedings (Corfu: Music Department, Ionian University), pp. 112-123 [in Greek].

[16] Lekkas, Demetrios E., 2003, i. "Vasika Diastimata ke Tropi sti Vizantini Mousiki” ("Basic Intervals and Modes in Byzantine Music"), text 10; ii. "Peri Aulōn Trēseōs" ("On the Drilling of Pipes"), text 13; in: Synodeutika Keimena gia tin Thematiki Enotita "Technes II: Episkopisi Ellinikis Mousikis ke Chorou" ELP 40 (Accompanying Texts for the Course "Arts II: Overview of Greek Music and Dance" ELP 40) (Patras: Greek Open University Press) [in Greek].

[17] Lekkas, Demetrios E., 2003, "Mousika Theoritika stous Mesous Chronous" ("Music Theoretics in the Middle Ages"); in: Technes II: Episkopisi Ellinikis Mousikis ke Chorou (Arts II: Overview of Greek Music and Dance"), vol. B: Elliniki Mousiki Praxi: Arkhei ke Mesi Chroni (Greek Musical Practice: Ancient and Middle Ages), pp. 177-195 (Patras: Greek Open University Press) [in Greek]. 
[18] Lekkas, Demetrios E., 2006, “I Diatoniki Vasi tis Vizantinis Mousikis: Systimiki Domiki Prosengisi" ("The Diatonic Basis of Byzantine Music: Systemic Structural Approach"); in: Polyphonia, 8, 7-35 (Athens) [in Greek].

[19] el-Mahdi, Salah, 1972, La Musique Arabe (Paris: Alphonse Leduc) [in French].

[20] Maqam World, 2001-2005, renovated 2016, website accessible online starting at: http://www.maqamworld.com/en/index.php.

[21] Michaelides, Solon, 1978, The Music of Ancient Greece: an Encyclopaedia (London: Faber and Faber Limited).

[22] Monzo, Joe, 2021, (with Paul Erlich, John Chalmers, Manuel Op de Coul, Margo Schulter, Carl Lumma), "Equal-Temperament", Tonalsoft: Encyclopedia of Microtonal Music Theory, accessible online at: http://www.tonalsoft.com/enc/e/equal-temperament.aspx.

[23] Nettl, Bruno, 1979, I Mousiki stous Protogonous Politismous (Athens: Kalvos), Greek translation by Costas Grimaldis of: 1956 / 1969, Music in Primitive Culture (Boston: Harvard University Press).

[24] Parfitt, David, 2001-2004, The Oud [August 2006]; sections cited:

a. "Music Notation": http://www.oud.eclipse.co.uk/notation.html;

b. "Arab Notes": http://www.oud.eclipse.co.uk/arabnotes.html;

c. "Turkish Notes": http://www.oud.eclipse.co.uk/turkishnotes.html.

Excellent site last accessed in August 2006; it has closed down since then. The critical body of the material has been salvaged, collected and edited by Katsoulas, Vangelis, 2021, see Ref. [14] above. Also recommended: Bilitzky, Hagay, 2021, see Ref. [3] above.

[25] Ptolemy, Claudius, Harmonics; in: Barker Andrew (editor): 1989, Greek Musical Writings, vol. ii: "Harmonic and Acoustic Theory", ch. 11: 270-291, Cambridge Readings in the Literature of Music (Cambridge University Press) $\left[2^{\text {nd }}\right.$ c. CE text in Greek].

[26] Sachs, Curt, 1943, The Rise of Music in the Ancient World: East and West (New York: W.W. Norton).

[27] Schlesinger, Kathleen, 1939, The Greek Aulos: a Study of its Mechanism and of its Relation to the Modal System of Ancient Greek Music, Followed by a Survey of the Greek Harmoniai in Survival or Rebirth in FolkMusic (with an Introduction by J.F. Mountford) (London: Methuen \& Co. Ltd.).

[28] al-Shalchi, Zeyad Kasem, 2021, blogger (various themes about Iraqi maqams): https://iraqimaqam.blogspot.com/p/glossary-of-terms.html.

[29] Smith, Eli, 1849, "A Treatise on Arab Music Chiefly from a Work by Mikhâil Meshâkah of Damascus"; in: Journal of the American Oriental Society iii, pp. 171-217.

[30] Spyrakis, Ioannis, 2006, The Greek Page on Byzantine Music, accessible online at: http://www.byzantinemusics.com [in Greek and English].

[31] Şençalar, İsmail, Kanuni, 1976, Kanun Öğrenme Metodu (Qanun Learning Method); Müzik Dünyasi yayınlarından: 2 (İstanbul: Ekspres Matbaası) [in Turkish].

[32] Wikipedia, the Free Encyclopedia, 2021, "Persian Traditional Music", accessible online at: https://en.wikipedia.org/wiki/Persian traditional music.

[33] Wikipedia, the Free Encyclopedia, 2021, "53 Equal Temperament", accessible online at: https://en.wikipedia.org/wiki/53 equal temperament\#History.

[34] Wikipedia, the Free Encyclopedia, 2021, "159edo", accessible online at: https://en.xen.wiki/w/159edo\#: :text=The\%20159\%20equal\%20divisions\%20of,243\%2F242\%2C\%20the\% 20rastma.

[35] Yasser, Joseph, 1932, A Theory of Evolving Tonality (New York: American Library of Musicology), facsimile paperback: 1975 (Boston: Da Capo Press Music reprint series).

[36] Yılmaz, Zeki, 1983, Türk Musikisi Dersleri (Turkish Music Lessons); (İstanbul: EGE Matbaası Vefa) [in Turkish].

[37] Illustrated information on the Jiahu flutes available online at website: http://www.shakuhachi.com/K-9KChineseFlutes-Nature.html. 